\title{
Campus Sexual Assault Adjudication: Why Universities Should Reject the Dear Colleague Letter
}

Tamara Rice Lave*

INTRODUCTION

In 2011, the Department of Education, Office of Civil Rights (OCR) responded to what many viewed as a crisis situation. A 2007 study had found that one in five women were victims of completed or attempted sexual assault while in college. ${ }^{1}$ Making matters worse, universities seemed either unable or unwilling to do anything about it. The problem was not just an inability to prevent sexual assault, but the way universities responded once it happened. Women complained that their allegations were not taken seriously, and even if someone was found responsible, the punishment was inadequate. One high-profile case involved two students at the University of Colorado who sued after they reported being repeatedly raped by football recruits. The case was settled out of court for $\$ 2.85$ million. $^{2}$

\footnotetext{
* Associate Professor, University of Miami School of Law. B.A., Haverford College; J.D., Stanford Law School; Ph.D., University of California, Berkeley. I am especially grateful to Michael Froomkin for his admirable patience in helping me work through the administrative law portion of this piece. I am also indebted to Gabriel (Jack) Chin, Donna Coker, Charlton Copeland, Osamudia James, Olatunde Johnson, Steve Schnably, Scott Sundby, and Bob Weisberg for their insightful comments and criticisms. I would also like to thank the participants at the 2016 University of Kansas Law Review Symposium and the 2015 New Voices in Legal Theory Roundtable for their helpful feedback. Finally, I would like to thank the editors at the University of Kansas Law Review (especially Abby Hall) for their careful editing.

1. See Christopher P. Krebs et al., The Campus Sexual Assault (CSA) Study: Final REPORT xiii (Oct. 2007), https://www.ncjrs.gov/pdffiles1/nij/grants/221153.pdf. Subsequent studies have found both higher and significantly lower levels of rape and sexual assault. See DAVID CANTOR, ET AL., REPORT ON THE AAU CAMPUS Climate SuRVEY ON SEXUAL ASSAUlt AND MisCoNDUCT, xiv (Sept. 21, 2015) (finding 33.1\% of college senior women reported being the victim of nonconsensual sexual touching at least once). But see SOFI SinOZICH \& LYNN LANGTON, U.S. DEP’T OF Justice, BuREAu OF Justice Statistics, SPECIAL REPORT: RAPE AND SEXUAL ASSAult Victimization AmONg College Age Females, 1995-2013 4 (Jill Thomas \& Lynne McConnell, eds., 2014) (finding the rate of rape and sexual assault for female college students was 6.1 per 1000).

2. Allison Sherry, CU Settles Case Stemming from Recruit Scandal, DENVER PosT (Dec. 6, 2007, 1:00 AM), http://www.denverpost.com/ci_7645722.
} 
In 2011, OCR issued its Dear Colleague Letter (DCL), in which it called the statistics on sexual violence "deeply troubling and a call to action for the nation." 3 OCR reminded universities that sexual violence constitutes a form of discrimination under Title IX. ${ }^{4}$ It told universities that in order to be in compliance, they had to change disciplinary proceedings to more effectively hold rapists accountable. ${ }^{5}$ In no uncertain terms, OCR told universities that they had to reduce the standard of proof in disciplinary proceedings to a preponderance of the evidence, and it strongly discouraged them from allowing the parties to directly question one another. ${ }^{6}$ It also told universities that they should not allow the respondent to review the complainant's statement unless she was able to review his. ${ }^{7}$ OCR threatened to withhold federal funding to universities that did not adequately respond, ${ }^{8}$ and it later published a list that continues to grow of those under investigation. ${ }^{9}$ OCR has found that a number of schools were in violation of Title IX, including Princeton University ${ }^{10}$ and Harvard Law School. ${ }^{11}$ These schools have since reached settlements with OCR, in which they agreed to change the way they handle sexual assault so as to meet the protocol set forth in the DCL. ${ }^{12}$

Some applaud OCR's efforts, ${ }^{13}$ but others contend that universities have gone too far in sacrificing the rights of the accused. ${ }^{14}$ Members of

3. Letter from Russlyn Ali, Assistant Sec'y for Civil Rights, U.S. Dep't of Educ., Office for Civil Rights, to Title IX Coordinators 2 (Apr. 4, 2011) [hereinafter Dear Colleague Letter], http://www2.ed.gov/about/offices/list/ocr/letters/colleague-201104.pdf.

4. Id. at 1 .

5. Id. at $1-3,7-14$.

6. Id. at $11-12$.

7. Id.

8. Id. at 26.

9. See infra notes $81-89$ and accompanying text.

10. Press Office, Princeton University Found in Violation of Title IX, Reaches Agreement with U.S. Education Department to Address, Prevent Sexual Assault and Harassment of Students, U.S. DEP'T OF EDUC. (Nov. 5, 2014), http://www.ed.gov/news/press-releases/princeton-university-foundviolation-title-ix-reaches-agreement-us-education-department-address-prevent-sexual-assault-andharassment-students [hereinafter Princeton Violation].

11. Press Office, Harvard Law School Found in Violation of Title IX, Agrees to Remedy Sexual Harassment, Including Sexual Assault of Students, U.S. DEP'T OF EDUC. (Dec. 30, 2014), http://www.ed.gov/news/press-releases/harvard-law-school-found-violation-title-ix-agrees-remedysexual-harassment-including-sexual-assault-students [hereinafter Harvard Violation].

12. See Princeton Violation, supra note 10; Harvard Violation, supra note 11.

13. See Lavinia M. Weizel, Note, The Process that is Due: Preponderance of the Evidence as the Standard of Proof for University Adjudications of Student-on-Student Sexual Assault Complaints, 53 B.C. L. REv. 1613, 1642-55 (2012); Amy Chmielewski, Note, Defending The Preponderance of The Evidence Standard in College Adjudications of Sexual Assault, 2013 BYU EDUC. \& L.J. 143, 149-74 (2013).

14. See William A. Jacobsen, Accused on Campus: Charges Dropped, But the Infamy Remains, 
the law faculty at both Harvard ${ }^{15}$ and the University of Pennsylvania ${ }^{16}$ have publicly called for greater procedural rights for the accused, and a Senior Fellow at Stanford University's Hoover Institute has decried OCR's Dear Colleague Letter for "institutionalizing a presumption of guilt in sexual assault cases." ${ }^{\prime 7}$ The popular press has also started to call attention to the experiences of men who say their universities never gave them a meaningful chance to defend themselves before finding them responsible for rape and expelling them. ${ }^{18}$

More importantly, Congress and the courts are starting to take notice of the impact the DCL has had on college campuses. On January 7 , 2016, in a move that may signal the demise of the DCL in a Republican controlled Congress, Senator James Lankford, Chairman of the Subcommittee on Regulatory Affairs and Federal Management, U.S. Senate Committee on Government Affairs and Homeland Security, wrote a letter to the Acting Secretary for the Department of Education demanding that DOE provide statutory authority for the DCL. ${ }^{19}$ Although Catherine

LEGAL INSURRECTION (May 16, 2015, 8:30 PM), http://legalinsurrection.com/2015/05/accused-oncampus-charges-dropped-but-the-infamy-remains/; see also Naomi Shatz, Feminists, We Are Not Winning the War on Campus Sexual Assault, Huffington Post (Oct. 29, 2014, 6:44 PM), http://www.huffingtonpost.com/naomi-shatz/feminists-we-are-not-winn_b_6071500.html; Stephen Henrick, A Hostile Environment for Student Defendants: Title IX and Sexual Assault on College Campuses, 40 N. KY. L. REV. 49 (2013); Barclay Sutton Hendrix, Note, A Feather on One Side, A Brick on the Other: Tilting the Scale Against Males Accused of Sexual Assault in Campus Disciplinary Proceedings, 47 GA. L. REV. 591, 599 (2013); Ryan D. Ellis, Mandating Injustice: The Preponderance of the Evidence Mandate Creates a New Threat to Due Process on Campus, 32 REV. LITIG. 65, 80-81 (2013).

15. Elizabeth Bartholet et al., Rethink Harvard's Sexual Harassment Policy, Boston GLOBE (Oct. 15, 2014), https://www.bostonglobe.com/opinion/2014/10/14/rethink-harvard-sexualharassment-policy/HFDDiZN7nU2UwuUuWMnqbM/story.html.

16. David Rudovsky et al., Open Letter from Members of the Penn Law School Faculty, Sexual Assault Complaints: Protecting Complainants and the Accused Students at Universities, PHILLY.COM (Feb. 18, 2015), http://media.philly.com/documents/OpenLetter.pdf.

17. Peter Berkowitz, College Rape Accusations and the Presumption of Male Guilt, WaLl ST. $\mathrm{J}$. (Aug. 20 , 2011) http://www.wsj.com/articles/SB10001424053111903596904576516232905230642.

18. Tovia Smith, Some Accused of Sexual Assault on Campus Say System Works Against Them, NPR (Sept. 3, 2014, 1:12 PM), http://www.npr.org/2014/09/03/345312997/some-accused-ofcampus-assault-say-the-system-works-against-them; Emily Yoffe, The College Rape Overcorrec-

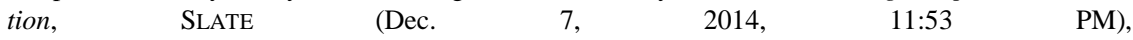
http://www.slate.com/articles/double_x/doublex/2014/12/college_rape_campus_sexual_assault_is_a _serious_problem_but_the_efforts.html; Teresa Watanabe, More College Men Are Fighting Back Against Sexual Misconduct Cases, L.A. Times (June 7, 2014, 6:15 PM), http://www.latimes.com/local/la-me-sexual-assault-legal-20140608-story.html.

19. Letter from Senator James Lankford, Chairman, Subcommittee on Regulatory Affairs and Fed. Mgmt., U.S. Senate Committee on Homeland Security and Gov't Affairs, U.S. Senate, to The Hon. John B. King, Jr., Acting Sec'y, U.S. Dep't of Educ. (Jan. 7, 2016) http://www.scribd.com/doc/294821262/Sen-Lankford-letter-to-Education-Department. 
E. Lhamon, the Assistant Secretary for Civil Rights, wrote a response, ${ }^{20}$ Lankford was not satisfied:

I again call on you to personally clarify that these policies are not required by Title IX, but reflect only one of various ways schools may choose to develop and implement policies for the prevention and remedy of sexual harassment and sexual violence that best meet the needs of their students and are compliant with federal law. I further ask that you immediately rein in the regulatory abuses within the Department of Education and take measures to ensure that all existing and future guidance documents issued by your agency are clearly and firmly rooted in statutory authority. ${ }^{21}$

Even if Congress does not pass legislation that specifically strikes down the DCL, courts across the country have been finding that current protections violate procedural due process. ${ }^{22}$ For example, in July 2015 a judge ordered the University of California, San Diego to reverse the suspension of a male student because the disciplinary proceedings violated his due process rights, ${ }^{23}$ and nine months later, a different judge overturned the suspension of a University of Southern California student on the ground that he was denied a fair hearing and the substantive evidence did not support the Appeal Panel's findings. ${ }^{24}$ On March 31, 2016, the Massachusetts District Court ruled in favor of a Brandeis University student who had been found responsible for "serious sexual transgressions." 25 The court wrote, "Brandeis appears to have substantially impaired, if not eliminated, an accused student's right to a fair and impartial process." 26 The court was particularly troubled by the deprivation of the

20. Letter from Catherine E. Lhamon, Assistant Sec'y of Civil Rights, to The Hon. James Lankford, Chairman, Subcommittee on Regulatory Affairs and Fed. Mgmt., Committee on Homeland Security and Gov't Affairs, U.S. Senate, (Feb. 17, 2016) http://chronicle.com/items/biz/pdf/DEPT.\%20of\%20EDUCATION\%20RESPONSE\%20TO\%20LA NKFORD\%20LETTER\%202-17-16.pdf.

21. Letter from Senator James Lankford, Chairman, Subcommittee on Regulatory Affairs and Fed. Mgmt., U.S. Senate Committee on Homeland Security and Gov't Affairs, U.S. Senate, to The Hon. John B. King, Jr., Acting Sec'y, U.S. Dep't of Educ. (Mar. 4, 2016) http://www.lankford.senate.gov/imo/media/doc/3.4.16\%20Lankford\%20letter\%20to\%20Dept.\%20of $\% 20$ Education.pdf.

22. See Jake New, Court Wins for Accused, InSIDE Higher Educ. (Nov. 5, 2015), https://www.insidehighered.com/news/2015/11/05/more-students-punished-over-sexual-assault-arewinning-lawsuits-against-colleges.

23. Doe v. Regents of the Univ. of Cal. San Diego, No. 37-2015-00010549-CU-WM-CTL, 2015 WL 4394597, at *4 (Cal. Super. Ct. July 10, 2015).

24. Doe v. Univ. of S. Cal., 200 Cal. Rptr. 3d 851, 877 (Cal. Ct. App. 2016).

25. Doe v. Brandeis Univ., No. 15-11557-FDS, 2016 WL 1274533, at*4 (D. Mass. Mar. 31, 2016).

26. Id. at *6. 
right to cross-examine ${ }^{27}$ as well as the lack of notice about the underlying allegations. $^{28}$

This Article contends that although well intentioned, the mandates of the DCL are not the best way to handle campus sexual assault. Universities should have a number of different options available, from restorative justice processes to a full-blown adjudicatory hearing. When suspension or expulsion may result, the respondent should have the right to an adjudicatory hearing with robust procedural rights. More controversially, this Article argues that despite the DCL, universities are legally entitled to make these changes.

This Article begins by situating university disciplinary proceedings legally and historically. It then turns to the DCL. It discusses whether OCR violated the Administrative Procedure Act (APA) by not going through notice and comment. After determining that the DCL is procedurally invalid, the Article discusses how universities can and should handle these cases while still remaining in compliance with Title IX. The Article concludes by acknowledging that even if schools would be allowed to make these changes they are unlikely to do so because of the considerable social (and indirect economic costs) in challenging the Department of Education.

\section{BACKGROUND}

1964 marked a watershed moment for equality in the United States. On July 2 of that year, President Lyndon B. Johnson signed the 1964 Civil Rights Act into law. ${ }^{29}$ Although much of the Act was aimed at preventing discrimination on the basis of race, color, religion, or national origin, ${ }^{30}$ Title VII—which banned workplace discrimination - specifi-

27. Id. at *34-35 ("While protection of victims of sexual assault from unnecessary harassment is a laudable goal, the elimination of such a basic protection for the rights of the accused raises profound concerns.... Here, there were essentially no third-party witnesses to any of the events in question, and there does not appear to have been any contemporary corroborating evidence. The entire investigation thus turned on the credibility of the accuser and the accused. Under the circumstances, the lack of an opportunity for cross-examination may have had a very substantial effect on the fairness of the proceeding.").

28. Id. at $* 34$.

29. Civil Rights Act of 1964, Pub. L. No. 88-352, 78 Stat. 241 (1964) (codified at 42 U.S.C. $\S$ $21(2012))$

30. Id. (Title II (Injunctive Relief Against Discrimination in Places of Public Accommodation); Title III (Desegregation of Public Facilities); Title IV (Desegregation of Public Education); Title VI (Nondiscrimination in Federally Assisted Programs)). 
cally included sex as a protected class. ${ }^{31}$ Eight years later, Congress extended the protection against sex discrimination to the classroom with Title IX. $^{32}$ Enacted as part of the Educational Amendments of 1972, Title IX barred sex discrimination in any education program or activity receiving federal financial assistance. ${ }^{33}$ Although there were exceptions, such as for fraternities, any institution that violated Title IX could lose federal funding. ${ }^{34}$

At first, Title IX was interpreted narrowly. ${ }^{35}$ In Grove City College v. Bell, the Supreme Court held that Title IX did not apply to an entire institution but just to the particular program receiving federal assistance. $^{36}$ Thus in Grove, the Court found that the receipt of federal tuition grants by students did not trigger Title IX coverage across the entire institution-but just of the school's financial aid program. ${ }^{37}$ Congress responded by enacting the Civil Rights Restoration Act of 1987 to clarify the "broad application of title IX." 38 It explicitly extended Title IX "to all of the operation[s] of . . . a college, university, or other postsecondary institution, or a public system of higher education . . . any part of which is extended Federal financial assistance." ${ }^{\prime 39}$

It took a while for courts to agree that Title IX extended to peer sexual harassment. In 1996, the Fifth Circuit affirmed summary judgment in favor of the school district on the ground that Title IX did not impose liability for peer sexual harassment because it only covered acts perpetrated by recipients of federal grants. ${ }^{40}$ One year later, the Eleventh Circuit held that Title IX only applied to sexual harassment perpetrated by employees and not by students. ${ }^{41}$ In Davis v. Monroe County Board of

\footnotetext{
31. Id. § 703(a)(1) (codified at 42 U.S.C. $§ 2000 \mathrm{e}-2(\mathrm{a})(2012)$ ).

32. Education Amendments of 1972, Pub. L. No. 92-318, §§ 901-03, 86 Stat. 235, 373-75 (1972) (codified at 20 U.S.C. $\$ 1681$ (2012)).

33. Id.

34. Id. $\S \S 901(\mathrm{a})(5), 902$.

35. See Trudy Saunders Bredthauer, Twenty-Five Years Under Title IX: Have We Made Progress?, 31 CREIGHTON L. REV. 1107, 1108-09 (1998); Jollee Faber, Expanding Title IX of the Education Amendments of 1972 to Prohibit Student to Student Sexual Harassment, 2 UCLA WoMEN'S L.J. 85, 113 n.119 (1992).

36. Grove City Coll. v. Bell, 465 U.S. 555, 573-74 (1984).

37. Id.

38. Civil Rights Restoration Act of 1987, Pub. L. No. 100-259, 102 Stat. 28, § 2(1) (1998).

39. Id. $\S 908(2)(\mathrm{A})$. Note that the law actually reached more broadly, to extend for instance to "a department, agency, special purpose district, or other instrumentality of a State or of a local government." Id. § 908(1)(A).

40. Rowinsky v. Bryan Indep. Sch. Dist., 80 F.3d 1006, 1008 (5th Cir. 1996).

41. Davis v. Monroe Cty. Bd. of Educ., 120 F.3d 1390, 1406 (11th Cir. 1997), rev'd, 526 U.S. 629 (1999).
} 
Education, the Supreme Court answered the question definitively, holding that Title IX did apply to peer-on-peer sexual harassment. ${ }^{42}$ In an opinion authored by Justice Kennedy, the Court wrote: "Having previously held that such harassment is 'discrimination' in the school context under Title IX, this court is constrained to conclude that student-onstudent sexual harassment, if sufficiently severe, can likewise rise to the level of discrimination actionable under the statute." 43

The Court determined further that a school could be held liable for monetary damages in a private lawsuit if one student sexually harasses another in the school's program. ${ }^{44}$ To prevail, the complainant had to meet the conditions of notice and indifference set forth in Gebser v. Lago Vista Independent School District. ${ }^{45}$ Gebser had relied on OCR's 1997 "Policy Guidance" in arguing that the school district should be liable when "a teacher is 'aided in carrying out the sexual harassment of students by his or her position of authority with the institution,' irrespective of whether school district officials had any knowledge of the harassment and irrespective of their response upon becoming aware."46

The Court found that OCR's standard was not sufficiently demanding. "[W]e will not hold a school district liable in damages under Title IX for a teacher's sexual harassment of a student absent actual notice and deliberate indifference. ${ }^{, 47}$ Instead, the Court held that the plaintiff had to prove that "an official who at a minimum has authority to address the alleged discrimination and to institute corrective measures on the recipient's behalf has actual knowledge of discrimination in the recipient's programs" and "refuses to take action to bring the recipient into compliance." 48

These rulings were significant because they extended the federal government's power to police colleges and universities. As long as a school received federal funding, the institution was required to comply

42. Davis v. Monroe Cty. Bd. of Educ., 526 U.S. 629, 633 (1999).

43. Id. at 650 .

44. Davis, 526 U.S. at $641-42,651$. The Court had previously held in Franklin v. Gwinnet County Public Schools, 503 U.S. 60 (1992), that students had a private right to damages when their Title IX rights were violated.

45. Davis, 526 U.S. at 629, 641-42, 651 (citing Gebser v. Lago Vista Indep. Sch. Dist., 524 U.S. 274 (1998)).

46. Id. at 282 (quoting Department of Education, Office for Civil Rights, Sexual Harassment Policy Guidance: Harassment of Students by School Employees, Other Students, or Third Parties, 62 Fed. Reg. 12034, 12039 (1997)).

47. Gebser, 524 U.S. at 292-93.

48. Id. at 290 . 
with Title IX. And since institutions were now liable for the harassment of one student against another if they had actual notice and were deliberately indifferent, they could no longer afford to just ignore what happened in dorm rooms and fraternities. At the same time, however, the Court showed that it would not hesitate to reign in the Department of Education (DOE) if the justices disagreed with DOE's interpretation of Title IX.

Despite the high standard of proof for liability, universities face significant lawsuits. United Educator (UE), which provides insurance to 1,200-member universities, recently began offering insurance to cover sexual assault payouts. Between 2006 and 2010, UE paid out \$36 million; $72 \%$ of the settlements were provided to parties suing the schools for incidents of sexual assault. ${ }^{49}$ In 2014 the University of Connecticut settled a $\$ 1.28$ million suit, and the University of Colorado at Boulder settled a suit for $\$ 825$ thousand. $^{50}$

\section{A. Department of Education, Office of Civil Rights}

Congress explicitly left enforcement of Title IX in the hands of the departments and agencies that allocated federal funds to education programs and/or activities. These agencies were "authorized and directed" to effectuate the prohibition against sexual discrimination. ${ }^{51}$ They were supposed to do so "by issuing rules, regulations, or orders of general applicability.",52 Compliance with these rules could be achieved "(1) by the termination of or refusal to grant or to continue assistance under such program or activity ... or (2) by any other means authorized by law., 53 OCR has published three guides to how schools should adjudicate sexual cases.

\section{1997 Guide}

In 1997, OCR published its first official guidance in the Federal Register on how schools should investigate and resolve allegations of sexual

\footnotetext{
49. Gayle Nelson, The High Cost of Sexual Assaults on Campuses, Non Profit QuARTERLY (June 23, 2015), https://nonprofitquarterly.org/2015/06/23/the-high-cost-of-sexual-assaults-oncollege-campuses/.

50. United Educators, Large Loss Report 2015, UE.ORG (2015), https://www.ue.org/uploadedFiles/Large_loss_2015_Final.pdf.

51. 20 U.S.C. $§ 1682$ (2012).

52. $I d$.

53. Id.
} 
harassment. ${ }^{54}$ Before drafting the document, OCR met with representatives from interested parties, including students, teachers, school administrators and researchers. ${ }^{55}$ It also twice publicly requested comments. ${ }^{56}$

In the 1997 guide, OCR enumerated certain factors that grievance procedures should contain in order to be in compliance with Title IX. They included provisions providing for notice to students and other interested parties, such as "(a)dequate, reliable and impartial investigation of complaints, including the opportunity to present witnesses and other evidence"; "designated and reasonably prompt time frames for the major stages of the complaint process"; notice of the outcome to the parties; and "an assurance that the school will take steps to prevent reoccurrence of any harassment and to correct its discriminatory effects on the complainant and others, if appropriate. ${ }^{, 57}$ OCR did not require that schools create a separate policy to deal with sexual harassment but instead explicitly permitted schools to use a general student disciplinary procedure. $^{5}$

The 1997 Guide also discussed the due process rights of the accused. OCR wrote " $[\mathrm{t}]$ he rights established under Title IX must be interpreted consistently with any federally guaranteed rights involved in a complaint proceeding." ${ }^{, 5}$ In addition to constitutional rights, OCR recognized that there could be additional rights created by state law, institutional regulations and policies as well as collective bargaining. ${ }^{60}$ OCR emphasized that respecting the procedural rights of both parties was an important part of a just outcome. "Indeed, procedures that ensure the Title IX rights of the complainant while at the same time according due process to both parties involved will lead to sound and supportable decisions. Schools should ensure that steps to accord due process rights do not restrict or unnecessarily delay the protections provided by Title IX to the complainant." ${ }^{, 1}$

As mentioned earlier, in Gebser v. Lago Vista Independent School

54. U.S. Department of Education, Office of Civil Rights, Sexual Harassment Guidance: Harassment of Students by School Employees, Other Students, or Third Parties, U.S. DEP'T OF EDUC. (Mar. 13, 1997), http://www2.ed.gov/about/offices/list/ocr/docs/sexhar01.html [hereinafter OCR 1997].

55. Id.

56. Id.

57. $I d$.

58. $I d$

59. Id.

60. Id.

61. Id. 
District, the Supreme Court struck down part of the 1997 Guidance Document concerning what showing should be required to recover damages under Title IX. ${ }^{62}$ Gebser contended that the standard should be that set forth in the 1997 Policy Guidance, ${ }^{63}$ which allowed liability "for even one instance of quid pro quo harassment by a school employee in a position of authority, such as a teacher or administrator, whether or not it knew, should have known, or approved of the harassment at issue." ${ }^{64}$ Gebser argued that the Policy Guidance was entitled to "considerable weight" and was "reasonable and fully consistent with the language and the purpose of the statute." 65 The Supreme Court disagreed with Gebser and by implication OCR, holding that to recover damages, a plaintiff must show both knowledge ${ }^{66}$ and deliberate indifference. ${ }^{67}$

\section{2001 Guide}

In 2001, OCR published a revised guide to sexual harassment under Title IX in the Federal Register principally in response to the Supreme Court's rulings in Gebser and Davis. ${ }^{68}$ As with the 1997 Guide, the 2001

62. See Gebser v. Lago Vista Indep. Sch. Dist., 524 U.S. 274 (1998).

63. Id. at 282 .

64. See OCR 1997, supra note 54 (“A school's liability for sexual harassment by its employees is determined by application of agency principles, i.e., by principles governing the delegation of authority to or authorization of another person to act on one's behalf. Accordingly, a school will always be liable for even one instance of quid pro quo harassment by a school employee in a position of authority, such as a teacher or administrator, whether or not it knew, should have known, or approved of the harassment at issue.").

65. Brief for Petitioner at 60-61, Gebser v. Lago Vista Indep. Sch. Dist., 118 S. Ct. 1989 (1998) (No. 96-1866), 1998 WL 19745 ("The Court has 'long recognized that considerable weight should be accorded to an executive department's construction of a statutory scheme it is entrusted to administer.' Moreover, as we have explained, the OCR's interpretation of Title IX and the scope of school district liability, and particularly its imposition of liability for the acts of those who are aided in carrying out harassment by the authority granted over students, is reasonable and fully consistent with the language and the purpose of the statute." (internal citations omitted)).

66. Gebser, 524 U.S. at 285 (“[W]e conclude that it would 'frustrate the purposes' of Title IX to permit a damages recovery against a school district for a teacher's sexual harassment of a student based on principles of respondeat superior or constructive notice, i.e., without actual notice to a school district official.").

67. Id. at 290-91 ("We think, moreover, that the response must amount to deliberate indifference to discrimination. The administrative enforcement scheme presupposes that an official who is advised of a Title IX violation refuses to take action to bring the recipient into compliance. The premise, in other words, is an official decision by the recipient not to remedy the violation. That framework finds a rough parallel in the standard of deliberate indifference. Under a lower standard, there would be a risk that the recipient would be liable in damages not for its own official decision but instead for its employees' independent actions.").

68. U.S. Department of Education, Office for Civil Rights, Revised Sexual Harassment Guidance: Harassment of Students by School Employees, Other Students or Third Parties, U.S. DEP'T OF 
Guide went through notice and comment. ${ }^{69}$ Although the Supreme Court had rejected the standard of liability advocated by OCR for liability in private lawsuits, OCR emphasized that it still had the power to "promulgate and enforce requirements that effectuate [Title IX's] nondiscrimination mandate, even in circumstances that would not give rise to a claim for money damages." 70

As compared with the 1997 Guide, the biggest change to the 2001's section on adjudication of sexual harassment complaints had to do with its increased emphasis on the rights of the accused. The 2001 Guide now had a section entitled, "Due Process Rights of the Accused." addition to being slightly reorganized, this newly appointed section told schools "the Family Rights and Privacy Act (FERPA) does not override federally protected due process rights of persons accused of sexual harassment." 72 It concluded by saying: "Schools should be aware of these rights and their legal responsibilities to individuals accused of harassment."73

\section{2011 Dear Colleague Letter}

In 2011, OCR issued the Dear Colleague Letter (DCL), which it deemed to be a "significant policy document,"74 i.e. disclaiming any status as an independent legislative rule. OCR contended that the DCL "does not add requirements to applicable law, but provides information and examples to inform recipients about how OCR evaluates whether covered entities are complying with their legal obligation.",75

Unlike the 1997 and 2001 Guide, OCR did not post a formal notice requesting feedback on the proposed changes. Many university officials responsible for enforcing Title IX have voiced frustration with OCR for not requesting input. As a university administrator at a state flagship university stated, "I'm not sure if all of the mandates have been thought

\footnotetext{
EDUC. (Jan. 2001), https://www2.ed.gov/offices/OCR/archives/pdf/shguide.pdf, [hereinafter OCR 2001]. In the 1997 Guide, OCR said that the standard of liability for monetary damages should be "known or should have known," a standard that was clearly rejected in Gebser. See OCR 1997, supra note 54

69. OCR 2001, supra note 68 , at ii.

70. Id.

71. Id. at 22 .

72. $I d$.

73. Id.

74. Dear Colleague Letter, supra note 3 , at 1 .

75. Id. at $1 \mathrm{n} .1$.
} 
through for all universities in all universities' context, it feels like stuff is missing or there would have been benefit to talking to campus administrators who are already doing this."

OCR laid out a number of recommendations and requirements in the DCL, which will be discussed at length below. Three modifications to the disciplinary proceedings, however, are of particular note: (1) OCR strongly discouraged schools from allowing the parties to directly question one another; ${ }^{77}(2)$ OCR told schools that they "should not allow the alleged perpetrator to review the complainant's statement without also allowing the complainant to review the alleged perpetrator's statement"; ${ }^{78}$ and (3) OCR required schools to set the standard of proof at preponderance of the evidence rather than clear and convincing evidence that some schools had been using.

\section{B. Enforcement}

The Department of Education (DOE) is currently investigating 241 post-secondary institutions regarding the way they handle sexual violence. ${ }^{79}$ Although a university has never lost federal funding for violating Title IX, ${ }^{80}$ DOE seems to be taking a more aggressive stance. As mentioned earlier, OCR has found a number of schools to be in violation of Title IX, including Princeton ${ }^{81}$ and Harvard Law School. ${ }^{82}$ These schools have since reached settlements with OCR in which they agreed to change the way they handle sexual assault so as to meet the protocol set forth in the DCL. ${ }^{8}$

On May 1, 2014, DOE released a list of forty-four colleges and universities under investigation ${ }^{84}$ and the list continues to grow. This infor-

76. Telephone Interview with an administrator at a flagship state university (Nov. 14, 2014). This person was willing to be quoted on the record, but anonymously.

77. Dear Colleague Letter, supra note 3, at 11-12.

78. Id.

79. See Campus Sexual Assault Under Investigation, THE Chronicle of Higher Educ., http://projects.chronicle.com/titleix/ (last visited June 1, 2016).

80. As of May 1, 2014, no university had ever lost funding for violating Title IX. See Tyler Kingkade, 55 Colleges Face Sexual Assault Investigations, HufFInGTON Post (July 1, 2014, 11:22 AM), http://www.huffingtonpost.com/2014/05/01/college-sexual-assault_n_5247267.html.

81. Princeton Violation, supra note 10.

82. Id.; Harvard Violation, supra note 11.

83. See Princeton Violation, supra note 10; Harvard Violation, supra note 11.

84. Press Office, U.S. Department of Education Releases List of Higher Education Institutions with Open Title IX Sexual Violence Investigations, DEP'T OF EDUC. (May 1, 2014), http://www.ed.gov/news/press-releases/us-department-education-releases-list-higher-education- 
mation was released even though the Equal Employment Opportunity Commission (EEOC) is statutorily barred from releasing the names of those under investigation in Title VII cases, ${ }^{85}$ and "(a)ny person who makes public information in violation of this subsection shall be fined not more than $\$ 1,000$ or imprisoned for not more than one year, or both." ${ }^{, 86}$ Similarly, the Department of Justice has an explicit policy against releasing information on current investigations except in unusual circumstances. $^{87}$ The reason for this non-disclosure policy is in part because "Justice Department guidelines, rules of professional conduct, and rules of court, as well as considerations of fairness to defendants, require that we not make comments that could prejudice a defendant's right to a fair trial." 88 Even if universities don't take the threat of losing federal funding seriously, such public shaming may have an effect. Two recent news articles have discussed how universities under suspicion for violating Title IX are receiving fewer applications from prospective students and fewer donations from alumnae. ${ }^{89}$

\section{IS THE DEAR COLLEAGUE LETTER PROCEDURALLY VALID?}

Determining whether universities must comply with the Dear Colleague Letter requires figuring out whether it is legally valid. That hinges on whether it is a legislative rule, an interpretive rule or merely some form of guidance document. OCR claims that the DCL is a "significant guidance document," but courts have sometimes held that a guidance document can contain interpretive rules. ${ }^{90}$ In either case, so long as the DCL does not contain matters that can only be promulgated via a legislative rule, ${ }^{91}$ it would not need to go through formal rulemaking or infor-

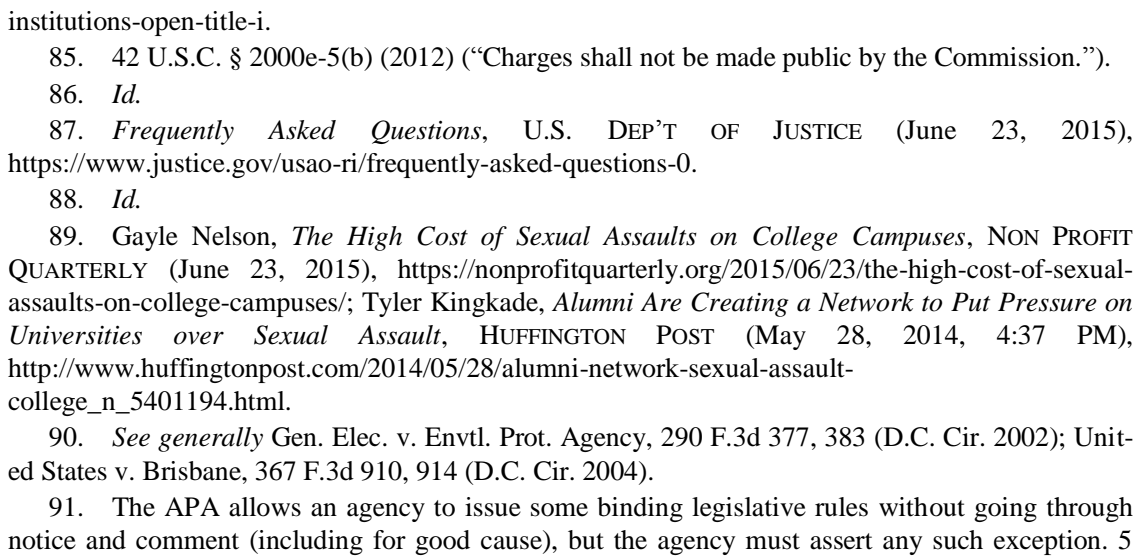
QUARTERLY (June 23, 2015), https://nonprofitquarterly.org/2015/06/23/the-high-cost-of-sexualassaults-on-college-campuses/; Tyler Kingkade, Alumni Are Creating a Network to Put Pressure on Universities over Sexual Assault, HufFInGTON Post (May 28, 2014, 4:37 PM), http://www.huffingtonpost.com/2014/05/28/alumni-network-sexual-assaultcollege_n_5401194.html.

90. See generally Gen. Elec. v. Envtl. Prot. Agency, 290 F.3d 377, 383 (D.C. Cir. 2002); United States v. Brisbane, 367 F.3d 910, 914 (D.C. Cir. 2004).

91. The APA allows an agency to issue some binding legislative rules without going through notice and comment (including for good cause), but the agency must assert any such exception. 5 
mal rulemaking's notice and comment. ${ }^{92}$ If the DCL is actually a legislative rule, however, then it will be procedurally invalid for not having gone through the required rule making process. ${ }^{93}$

\section{A. Distinguishing Between Legislative and Non-Legislative Rules}

The Department of Education has been "authorized and directed" to enforce Title IX by issuing legislative rules. ${ }^{94}$ If substantively valid, legislative rules have "the force and effect of a statute on all those who are subject to [them] ... [and they] bind[] the agency, private parties, and the courts, and may preempt state statutes." 95 Interpretive rules, on the other hand, can be used to signal how an agency will interpret a rule, but they do not bind agencies or the public. ${ }^{96}$ Agencies are also allowed to issue guidance documents - a broad category of non-legislative rules, which includes "interpretive memoranda, policy statements, guidances, manuals, circulars, memoranda, bulletins, advisories, and the like." There is also a subset of guidance documents called "significant guidance documents," which is what the DCL purports to be. ${ }^{98}$

Because legislative rules are legally binding, the Administrative Procedure Act (APA) requires that they be promulgated in a way that allows for public input and participation. That means they must be created

\footnotetext{
U.S.C. § 553(b)(3)(B) (2012). Because the OCR did not assert this exception, the exception does not apply to the DCL.

92. 5 U.S.C. $\$ 553(\mathrm{~b})(3)(\mathrm{A})(2012)$

93. See infra Part II.A.

94. 20 U.S.C. $\$ 1682$ (2012).

95. Peter L. Strauss, Comment, The Rulemaking Continuum, 41 DuKE L. J. 1463, 1467 (1992).

96. Nina A. Mendelson, Regulatory Beneficiaries and Informal Agency Policymaking, 92 CORNELL L. REV. 397, 399-400 (2007).

97. Office of Management and Budget, Executive Office of the President, Final Bulletin for Agency Good Guidance Practices, 72 Fed. Reg. 3432, 3434 (Jan. 25, 2007) [hereinafter Final Bulletin].

98. Dear Colleague Letter, supra note 3 at 1 n.1. The Office of Management and Budget (OMB) has defined a significant guidance document as a guidance document which: may reasonably be anticipated to: (i) Lead to an annual effect on the economy of $\$ 100$ million or more or adversely affect in a material way the economy, a sector of the economy, productivity, competition, jobs, the environment, public health or safety, or State, local, or tribal governments or communities; or (ii) Create a serious inconsistency or otherwise interfere with an action taken or planned by another agency; or (iii) Materially alter the budgetary impact of entitlements, grants, user fees, or loan programs or the rights and obligations of recipients thereof; or (iv) Raise novel legal or policy issues arising out of legal mandates, the President's priorities, or the principles set forth in Executive Order 12866, as further amended.

Final Bulletin, supra note 97, at 3434.
} 
through formal rule making ${ }^{99}$ or by informal rule making, also known as notice-and-comment. ${ }^{100}$ Interpretive rules and guidance documents, on the other hand, do not have the force of law, and so they do not have to comply with these requirements. ${ }^{101}$ Because significant guidance documents have a greater impact than usual guidance documents, The Office of Management and Budget (OMB) requires that they pass through additional procedural hoops. "Not later than 180 days from the publication of this Bulletin, each agency shall establish and clearly advertise on its Web site a means for the public to submit electronically comments on significant guidance documents, and to request electronically that significant guidance documents be issued, reconsidered, modified or rescinded." $" 102$

Congress,${ }^{103}$ courts ${ }^{104}$ commentators,${ }^{105}$ and even the White House ${ }^{106}$ have been concerned that agencies abuse guidance documents by promulgating new laws without going through notice and comment. In 2007,

99. 5 U.S.C. $\S \S 553(\mathrm{c}), 556,557$ (2012). This process is more demanding and less common than notice and comment. David L. Franklin, Legislative Rules, Nonlegislative Rules, and the Perils of the Short Cut, 120 YALE L.J. 276, 282 (2010).

100. 5 U.S.C. $\S \S 553(b)(3)$, (c) (2012); Franklin, supra note 99, at 282.

101. 5 U.S.C. $\$ 553(\mathrm{~b})(\mathrm{A})$.

102. Final Bulletin, supra note 97, at 3437; Cf. Sean Croston, The Petition is Mightier than the Sword: Rediscovering an Old Weapon in the Battles Over "Regulation Through Guidance", 63 ADMIN. L. REV. 381, 382-83 (2011).

103. H.R. REP. No. 106-1009, at 1 (2000) ("Regrettably, the committee's investigation found that some guidance documents were intended to bypass the rulemaking process and expanded an agency's power beyond the point at which Congress said it should stop. Such 'backdoor' regulation is an abuse of power and a corruption of our Constitutional system.").

104. See Appalachian Power Co. v. Envtl. Prot. Agency, 208 F.3d 1015, 1020 (D.C. Cir. 2000). The D.C. Circuit noted:

The phenomenon we see in this case is familiar. Congress passes a broadly worded statute. The agency follows with regulations containing broad language, openended phrases, ambiguous standards and the like. Then as years pass, the agency issues circulars or guidance or memoranda, explaining, interpreting, defining and often expanding the commands in regulations. One guidance document may yield another and then another and so on. Several words in a regulation may spawn hundreds of pages of text as the agency offers more and more detail regarding what its regulations demand of regulated entities. Law is made, without notice and comment, without public participation, and without publication in the Federal Register

Id. or the Code of Federal Regulations.

105. See Mark Seidenfeld, Substituting Substantive for Procedural Review of Guidance Documents, 90 TEX. L. ReV. 331, 352 (2011); Robert A. Anthony, Interpretive Rules, Policy Statements, Guidances, Manuals and the Like-Should Federal Agencies Use Them to Bind the Public?, 41 DuKE L.J. 1311, 1327 (1992). But see Connor N. Raso, Note, Strategic or Sincere? Analyzing Agency Use of Guidance Documents, 119 YALE L.J. 782, 785 (2010).

106. Final Bulletin, supra note 97, at 3432 ("OMB has been concerned about the proper development and use of agency guidance documents.”). 
the Bush White House issued a Bulletin on Good Guidance Practices in an attempt to reign in these undemocratic processes. ${ }^{107}$ Still, the problem remains. Part of the reason why agencies are able to abuse guidance documents is that it is difficult to distinguish between legislative and non-legislative rules. David Franklin has called creating a workable distinction between the two perhaps the most "vexing conundrum in the field of administrative law"108 - no surprise considering that courts have said the distinction is "fuzzy"109 and "enshrouded in considerable smog." 110

As mentioned above, OCR termed the DCL a "significant guidance document"111 and did not promulgate it through formal rule making or notice and comment. The test for whether the DCL is a legislative rule and thus should have gone through the APA's required rulemaking processes is whether it has a "legally binding" effect. ${ }^{112}$

\section{B. Did the DCL Effectively Amend a Prior Legislative Rule?}

In American Mining Congress v. United States Department of Labor ${ }^{113}$ the D.C. Circuit set out a "particularly influential" ${ }^{114}$ formulation of the legal effect test. Determining whether a "purported interpretive rule" has legal effect can be "best ascertained by asking (1) "where, in the absence of a legislative rule by the agency, the legislative basis for

\footnotetext{
107. See id.
}

108. David L. Franklin, Legislative Rules, Nonlegislative Rules, and the Perils of the Short Cut, 120 YALE L.J. 276, 278 (2010). Franklin suggested what he called the "short cut" test as a way of simplifying the distinction between legislative and interpretive rules. If a rule goes through notice and comment it is legislative; if it does not, then it is interpretive. Id. at 279 . Under that test, the DCL would be a non-legislative rule because it did not go through notice and comment. Since nonlegislative rules do not need to go through notice and comment, the DCL would be procedurally valid. Id. Despite the beguiling simplicity of the short cut test, which would "economize on judicial decision costs by eliminating at one stroke the need for courts to divine the intrinsic nature or purpose of any challenged rule or to develop any elaborate test for distinguishing between legislative and nonlegislative rules," Franklin acknowledged that no courts have adopted it. Id. at 279, 294303.

109. Am. Hosp. Ass'n v. Bowen, 834 F.2d 1037, 1046 (D.C. Cir. 1987) (citing Cmty. Nutrition Inst. v. Young, 818 F.2d 943, 946 (D.C. Cir. 1987)).

110. Gen. Motors Corp. v. Ruckelshaus, 742 F.2d 1561, 1565 (D.C. Cir. 1984); Richard J. Pierce, Jr., Distinguishing Legislative Rules from Interpretive Rules, 52 ADMIN. L. REV. 547, 547-48 (2000).

111. Final Bulletin, supra note 97.

112. William Funk, A Primer on Nonlegislative Rules, 53 ADMIN. L. REV. 1321, 1326 (2001).

113. Am. Mining Cong. v. United States Dep't of Labor, 995 F.2d 1106 (D.C. Cir. 1993).

114. Peter L. Strauss Et Al., Administrative Law: Cases And Comments 194 (Foundation Press, 11th ed. (2011)). 
agency enforcement would be inadequate"; ${ }^{115}$ (2) whether the agency has published the rule in the Code of Federal Regulations; ${ }^{116}$ or (3) whether the rule effectively amends a prior legislative rule. ${ }^{117}$ If the answer to any of these questions is "yes," we have a legislative and not an interpretive rule. The last factor has been seen as the most important. ${ }^{118}$ The D.C. Circuit Court of Appeals has used all or part of this same test to determine if each of the following were legislative rules: a Federal Aviation Association internal guidance document, ${ }^{119}$ an EPA Guidance Document, ${ }^{120}$ and Training and Employment Guidance Letters issued by the Department of Labor. ${ }^{121}$ In other words, if the 2001 Guidance Document is legislative and the DCL effectively amended it, then it is a legislative rule and not an interpretative rule, a policy document, or a guidance document. If it is a legislative rule, the DCL will be invalid.

1. Is the 2001 Guidance Document a Legislative Rule?

Deciding whether the DCL amends a legislative rule requires first determining whether the 2001 Guidance Document, which the DCL amends and sometimes replaces, is itself a legislative rule. In issuing the 2001 Guidance Document, OCR explicitly invoked its general authority, ${ }^{122}$ and it used mandatory language. ${ }^{123}$ Although the agency did not actually claim it was engaged in rule making in 2001, it complied with all the requirements for rule making and probably needed to do so to make some of the pronouncements in that document legally valid.

The 2001 Guidance Document was issued in order to revise the 1997 Guidance Document in light of two Supreme Court decisions. ${ }^{124}$ Although the legal status of the 1997 Guidance could be debated, a strong argument exists that it was in fact what it proclaimed to be. On the one hand, OCR complied with the requirements for rule making, ${ }^{125}$ and the

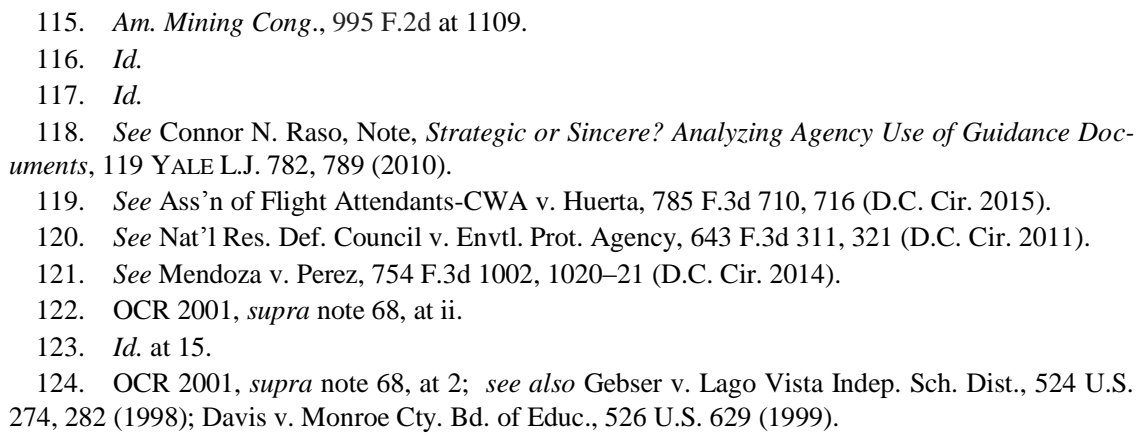


1997 policy Guidance was published in the Federal Register. ${ }^{126}$ On the other hand, unlike the 2001 Guidance Document and the DCL, OCR did not specifically invoke its authority to issue the 1997 Guidance Document. Nor did it use the kind of mandatory language that appeared in both the 2001 Guidance Document and the DCL. Additionally, in its amicus brief in Gebser, OCR explicitly referred to the 1997 Guidance Document as guidance and not a legislative rule. ${ }^{127}$

The 2001 Guidance Document was also published in the Federal Register, ${ }^{128}$ and OCR complied with the requirements for informal rule making by going through notice and comment. ${ }^{129}$ Unlike the 1997 Guidance, the 2001 Guidance Document contained the kind of mandatory language associated with legislative rules. For instance, it said, "Regardless of whether the student who was harassed, or his or her parent, decides to file a formal complaint or otherwise request action on the student's behalf . . . the school must promptly investigate to determine what occurred and then take appropriate steps to resolve the situation." 130 In contrast, the 1997 Guidance Document stated, "Once a school has notice of possible sexual harassment of students ... it should take immediate and appropriate steps to investigate or otherwise determine what occurred and take steps reasonably calculated to end any harassment, eliminate a hostile environment if one has been created, and prevent harassment from occurring again." 131

In light of the way that the 2001 Guidance Document was promulgated, the fact that OCR explicitly invoked its general legislative authority, and the fact that on at least one occasion it used mandatory language, there is a strong argument that it is a legislative rule.

126. See generally OCR 1997, supra note 54.

127. Brief for the United States as Amicus Curiae Supporting Petitioner at 43 n.18, Gebser v. Lago Vista Indep. Sch. Dist., 118 S. Ct. 1989 (1998) (No. 96-1866), 1998 WL 19745 ("In Rosa H., the Fifth Circuit declined to defer to the Department's policy guidance on sexual harassment in cases where the sexual harassment had occurred before issuance of the guidance. The court thereby mistakenly treated the guidance as legislative in nature-i.e., as prescribing new norms of conduct, rather than as an interpretation of an unchanged statutory provision." (citations omitted)) (Rosa H. refers to Rosa H. v. San Elizario Independent School District, 106 F.3d 648 (5th Cir. 1997)).

128. OCR 1997, supra note 54, at 12034.

129. OCR 2001, supra note 68, at 2 ("The guidance was the product of extensive consultation with interested parties, including students, teachers, school administrators, and researchers. We also made the document available for public comment.").

130. OCR 2001, supra note 68, at 15 (emphasis added).

131. OCR 1997, supra note 54, at 12042 (emphasis added). 
2. Did the DCL Effectively Amend the 2001 Guidance Document?

If the 2001 Guidance Document was a legislative rule, the key question is whether the DCL "effectively amended" it. Changes were made in a number of areas, including how schools should handle police investigations, what the standard of proof should be, requirements regarding witnesses, the provision of information, lawyers, the right to appeal, how notice should be provided, protocol for handling retaliation, mandates for providing remedies, and how OCR would enforce compliance. Note that even if the 2001 Guidance Document was not a legislative rule, the test from American Mining Congress will still be used to see if the DCL is invalid on its own for having legal effect. ${ }^{132}$

\section{a. Grievance Procedures}

The 2001 Guidance Document explicitly tells schools they are allowed to use informal mechanisms for resolving sexual harassment, as long as both parties agree. Later, it tells schools that mediation is inappropriate for sexual assault, even if parties would participate voluntarily:

Grievance procedures may include informal mechanisms for resolving sexual harassment complaints to be used if the parties agree to do so.... In some cases, such as alleged sexual assaults, mediation will not be appropriate even on a voluntary basis. 133

The DCL, however, limits the use of voluntary mechanisms to only some types of sexual harassment. The DCL also states that mediation is inappropriate in cases of sexual assault:

Grievance procedures generally may include voluntary informal mechanisms (e.g., mediation) for resolving some types of sexual harassment complaints. ... [I]n cases involving allegations of sexual assault, mediation is not appropriate even on a voluntary basis. ${ }^{134}$

The difference between the 2001 Guidance and the DCL is subtle but significant. Although the 2001 Guidance Document limits the use of mediation, it does not limit the use of other types of informal mechanisms. The DCL on the other hand seems to equate all informal mechanisms with mediation and limits their use. That means that a school

132. See text infra Part II.C.

133. OCR 2001, supra note 68, at 21.

134. Dear Colleague Letter, supra note 3 , at 8 . 
would have been able to implement restorative justice processes under the 2001 Guidance but probably not under the DCL.

\section{b. Police Investigation}

The 2001 Guidance Document had discussed how schools should handle an ongoing police investigation regarding the underlying harassment. Although it reminded schools that they had an obligation to respond promptly and effectively on their own regardless of whether there was an ongoing police investigation, it did not provide specifics about what they should do. The 2001 Guidance stated:

In some instances, a complainant may allege harassing conduct that constitutes both sex discrimination and possible criminal conduct. Police investigations or reports may be useful in terms of fact gathering. However, because legal standards for criminal investigations are different, police investigations or reports may not be determinative of whether harassment occurred under Title IX and do not relieve the school of its duty to respond promptly and effectively. ${ }^{135}$

The DCL, in contrast, provides much more elaborate instructions for what schools should do when there is a concurrent police investigation. As is evident from the text below, there is no flexibility in these instructions. OCR is telling schools what they must do to comply with their obligations under Title IX:

Schools should not wait for the conclusion of a criminal investigation or criminal proceedings to begin their own Title IX investigation and, if needed, must take immediate steps to protect the student in the educational setting. For example a school should not delay conducting its own investigation or taking steps to protect the complainant because it wants to see whether the alleged perpetrator will be found guilty of a crime. Any agreement or Memorandum of Understanding (MOU) with a local police department must allow the school to meet its Title IX obligation to resolve complaints promptly and equitably. Although a school may need to delay temporarily the fact-finding portion of a Title IX investigation while the police are gathering evidence, once notified that the police department has completed its gathering of evidence (not the ultimate outcome of the investigation or the filing of any charges), the school must promptly resume and complete its fact-finding for the Title IX investigation. Moreover, nothing in an MOU or the criminal investigation itself should prevent a school from notifying complainants of their Title XI rights and the school's grievance procedures, or from taking interim steps to ensure the

135. OCR 2001, supra note 68, at 21. 
safety and well-being of the complainant and the school community while the law enforcement agency's fact-gathering is in process. OCR also recommends that a school's MOU include clear policies on when a school will refer a matter to local law enforcement. ${ }^{136}$

The difference between the 2001 Guidance and the DCL is striking. The 2001 Guidance provided almost no direction regarding how schools should handle police investigations except to say that a police investigation may not be determinative of whether there was a Title IX violation and that schools still had an obligation to respond promptly and effectively. The DCL in contrast tells schools that they must not wait for an investigation to end but must take immediate steps to protect the complainant. It dictates the relationship between schools and the police, telling schools that any formal understanding between the police and schools must allow the schools to meet their Title IX obligation of prompt investigation. It then tells schools that even if they have to wait for the police to finish their investigation that they must promptly resume after the police fact-finding portion is done. In effect, DOE is telling schools what they must do without knowing the needs of law enforcement or the local prosecutor's office. One can imagine a university being placed in a difficult situation because law enforcement requests more time to investigate a case beyond the initial fact finding portion and believes that the school's investigation might impair their investigation but the school is left with no choice but to disregard law enforcement or face sanction from DOE.

\section{c. The Standard of Proof}

The 2001 Guidance Document contained a section on "Prompt and Equitable Grievance Procedures." 137 It specifically told schools that they did not need to set up separate grievance procedures for handling sexual harassment cases. ${ }^{138}$ It did "identif[y] a number of elements in evaluating whether a school's grievance procedures were prompt and equitable."139 These included notice, "[a]dequate, reliable, and impartial investigation of complaints, including the opportunity to present witnesses and other evidence" and "[d]esignated and reasonably prompt timeframes for

136. Dear Colleague Letter, supra note 3, at 10 (emphasis added).

137. OCR 2001, supra note 68, at 19.

138. Id.

139. Id. at 20 
the major stages of the complaint process."140 At no point did it tell schools that the standard of proof needed to be set at a certain level.

The DCL, in contrast, tells schools in unequivocal terms that the standard of proof must be set at preponderance of the evidence. It states, "in order for a school's grievance procedures to be consistent with Title IX standards, the school must use a preponderance of the evidence standard." 141 It also specifically acknowledges that in setting the standard of proof at preponderance, it will be forcing some schools to change their existing standard of proof. "The 'clear and convincing' standard ... currently used by some schools, is a higher standard of proof. Grievance procedures that use this higher standard are inconsistent with the standard of proof established for violations of the civil rights laws, and are thus not equitable under Title IX."142

\section{d. Witnesses and Information}

As mentioned above, the 2001 Guidance document identified a number of elements that the DOE looked for in evaluating whether the school's grievance procedures were prompt and equitable. Among others, it told schools that there must be "[a]dequate, reliable, and impartial investigation of complaints, including the opportunity to present witnesses and other evidence."143

The DCL, in contrast sets out new rules for how schools should institute this element. It states, "[ $\mathrm{t}] \mathrm{hroughout}$ a school's Title IX investigation, including at any hearing, the parties must have an equal opportunity to present witnesses and other evidence. The complainant and the alleged perpetrator must be afforded similar and timely access to any information that will be used at the hearing."

The DCL changed the student disciplinary procedure in fundamental ways. A school might have concluded that since the accused faces disciplinary sanction that it is he who should know the information that will be presented against him at the hearing and have the right to present evidence on his own behalf. The DCL has effectively altered the proceedings so that there are now three people putting on evidence: the school, the accused, and the complainant. By mandating the complainant's equal

140. Id.

141. Dear Colleague Letter, supra note 3, at 11 (emphasis added).

142. Id.

143. OCR 2001, supra note 68, at 20.

144. Dear Colleague Letter, supra note 3, at 11 (emphasis added). 
right to call witnesses and put on evidence it is extending the length of the hearings, and it is removing from schools the right to decide what evidence is relevant and should be admitted. Further, by requiring that both parties have similar and timely access to information, it is forcing schools to adjust their processes and shift resources so that they are able to meet these time requirements to two parties when before there was just one.

e. Lawyers

The 2001 Guidance document did not mention lawyers at all, thus taking no view as to whether the accused could or should have legal representation in university disciplinary proceedings. The DCL in contrast mandates that schools give parties equal access to attorneys and that both attorneys have the same restrictions on their ability to speak or put on evidence. It states:

While OCR does not require schools to permit parties to have lawyers at any stage of the proceedings, if a school chooses to allow the parties to have the lawyers participate in the proceedings, it must so do equally for both sides. Additionally, any school-imposed restrictions on the ability of lawyers to speak or otherwise participate in the proceeding should apply equally. 145

In effect, OCR limits a university's right to decide how it wants to handle counsel. Requiring that a school provide equal access and equal time may increase costs because if the school provides for counsel for the accused, it must now provide counsel for the complainant as well.

\section{f. Appeals}

The 2001 Guidance document acknowledges that some schools may provide a right to appeal, but it did not provide any particulars about the way it should work, saying only "[m]any schools also provide an opportunity to appeal the findings or remedy, or both." 146 The DCL, in contrast, adds specific requirements for the appeals process, if a school chooses to have one: "OCR also recommends that schools provide an appeals process. If a school provides for appeal of the findings or reme-

145. Id. at 12 (emphasis added).

146. OCR 2001, supra note 68, at 20. 
dy, it must do so for both parties."147

Once again, OCR is making the disciplinary process more resource expensive and time consuming since universities that once provided only the accused with the right to appeal must now provide that right to the complainant as well.

\section{g. Notice of Outcome}

The 2001 Guidance document told schools that one of the elements it would consider in evaluating its grievance procedures was whether it provided notice to the parties of the outcome. ${ }^{148}$ The document did not specify what form that notice should take. The DCL in contrast, tells schools that notice is required, and that it must be in writing: "Both parties must be notified, in writing, about the outcome of both the complaint and any appeal.",149

\section{h. Retaliation}

The 2001 Guidance document told schools that they "should take steps to prevent any further harassment and to prevent retaliation against the student who made the complaint (or was the subject of the harassment), against the person who filed a complaint on behalf of a student, or against those who provided information as witnesses."150 At a minimum, it said, schools should make sure that harassed students and their parents know how to report these problems and that the school should make follow up inquiries to see if there have been any additional incidents of retaliation. ${ }^{151}$ It then said that counseling may be appropriate for the offender and that depending on how widespread the harassment was, they may need to provide training to the larger community for recognizing harassment and knowing how to respond. ${ }^{152}$ Later it stated: "In addition, because retaliation is prohibited by Title IX, schools may want to include a provision in their procedures prohibiting retaliation against any individual who files a complaint or participates in a harassment inquiry." ${ }^{\prime 153}$

\footnotetext{
147. Dear Colleague Letter, supra note 3, at 12 (emphasis added).

148. OCR 2001, supra note 68, at 20.

149. Dear Colleague Letter, supra note 3, at 13 (emphasis added).

150. OCR 2001, supra note 68, at 17 (emphasis added).

151. Id. (emphasis added).

152. Id. (emphasis added).

153. Id. at 20 .
} 
The DCL, in contrast tells schools that they "must have policies and procedures in place to protect against retaliatory harassment." 154 It then mandates how this should be done. "At a minimum, schools must ensure that complainants and their parents, if appropriate, know how to report any subsequent problems, and should follow-up with complainants to determine whether any retaliation or new incidents of harassment have occurred." $" 155$

\title{
i. Remedies
}

The 2001 Guide told schools that they must respond immediately once they had notice of a student harassing another student. If they responded immediately, the 2001 Guide stated that they would not be responsible for taking additional steps:

\begin{abstract}
As long as the school, upon notice of the harassment, responds by taking prompt and effective action to end the harassment and prevent its recurrence, the school has carried out its responsibility under the Title IX regulations. On the other hand, if, upon notice, the school fails to take prompt, effective action, the school's own inaction has permitted the student to be subjected to a hostile environment that denies or limits the student's ability to participate in or benefit from the school's program on the basis of sex. In this case, the school is responsible for taking effective corrective actions to stop the harassment, prevent its recurrence, and remedy the effects on the victim that could reasonably have been prevented had it responded promptly and effectively. ${ }^{156}$
\end{abstract}

The DCL, in contrast, tells schools that they are responsible for remedying the effects on the victim regardless of whether they responded in a timely fashion:

As discussed above, if a school determines that sexual harassment that creates a hostile environment has occurred, it must take immediate action to eliminate the hostile environment, prevent its recurrence, and address its effects. In addition to counseling or taking disciplinary action against the harasser, effective corrective action may require remedies for the complainant, as well as changes to the school's overall services or policies. ... Depending on the specific nature of the problem, remedies for the complainant might include, but are not limited to: providing an escort to ensure that the complainant can move safely between classes and activities; ensuring that the complainant and alleged perpetrator do not attend the

154. Dear Colleague Letter, supra note 3, at 16 (emphasis added).

155. Id. (emphasis added).

156. OCR 2001, supra note 68, at 21. 
same classes; moving the complainant or alleged perpetrator to a different residence hall ... ; providing counseling services; providing medical services; providing academic support services, such as tutoring; arranging for the complainant to re-take a course or withdraw from a class without penalty, including ensuring that any changes do not adversely affect the complainant's academic record; and reviewing any disciplinary action taken against the complainant to see if there is a causal connection between the harassment and the misconduct that may have resulted in the complainant being disciplined. ${ }^{15}$

These changes are significant. The 2001 Guidance Document told schools that if, upon notice of harassment, they took prompt and effective action to end the harassment and prevent its recurrence they would have carried out their responsibility under Title IX. It was only if they did not take prompt and effective action that they would be responsible for remedying the effects of the harassment on the victim. In contrast, the DCL makes schools responsible for remedying the effects on the victim regardless of how quickly or effectively they responded. This change significantly increases the financial burden on schools, as they must now provide for extensive services that they would not have had to otherwise.

\section{j. Enforcement}

The DCL is also much more heavy-handed than the 2001 Guidance document on enforcement. The 2001 Guidance makes it clear that if a school takes certain steps it will be found to be in compliance with Title IX, even if actual harassment occurred. The Guidance states in relevant part:

If the school has taken, or agrees to take, each of these steps, OCR will consider the case against the school resolved and will take no further action, other than monitoring compliance with an agreement, if any, between the school and OCR. This is true in cases in which the school was in violation of the Title IX regulations ... as well as those in which there had been no violation of the regulations .... This is because, even if OCR identifies a violation, Title IX requires OCR to attempt to secure voluntary compliance. Thus, because a school will have the opportunity to take reasonable corrective action before OCR issues a formal finding of violation a school does not risk losing its Federal funding solely because discrimi-

157. Dear Colleague Letter, supra note 3, at 15-17. 
nation occurred. $^{158}$

The DCL, in contrast, takes a markedly more punitive tone. Although it acknowledges that it seeks voluntary compliance, it emphasizes the consequences of not complying instead of the positive effects of complying. The DCL states:

\begin{abstract}
When OCR finds that a school has not taken prompt and effective steps to respond to sexual harassment or violence, OCR will seek appropriate remedies for both the complainant and the broader student population. When conducting Title IX enforcement activities, OCR seeks to obtain voluntary compliance from recipients. When a recipient does not come into compliance voluntarily, OCR may initiate proceedings to withdraw Federal funding by the Department or refer the case to the U.S. Department of Justice for ligation.
\end{abstract}

\title{
k. General Tone
}

One striking part of the 2001 Guidance Document is its emphasis on the rights of the accused student. Just as with in the 1997 Guide, the 2001 Guide discussed the due process rights of the accused. In the 1997 Guide, OCR wrote "the rights established under title IX must be interpreted consistently with any federally guaranteed rights involved in a complaint proceeding." ${ }^{\text {"160 }}$ In addition to constitutional rights, OCR recognized in the 1997 Guide that state law, institutional regulations and policies and collective bargaining could create additional rights for accused students. ${ }^{161}$ In the 1997 Guide OCR emphasized that respecting the procedural rights of both parties was an important part of a just outcome. "Indeed, procedures that ensure the Title IX rights of the complainant while at the same time according due process to both parties involved will lead to sound and supportable decisions. ... Schools should ensure that steps to accord due process rights do not restrict or unnecessarily delay the protections provided by Title IX to the complainant."162

In comparison with the 1997 Guide, the 2001 Guide actually stressed the importance of the rights of the accused to an even greater degree. The 2001 guide included a new section entitled, "Due Process Rights of

\footnotetext{
158. OCR 2001, supra note 68, at 14-15.

159. Dear Colleague Letter, supra note 3, at 16.

160. OCR 1997, supra note 54.

161. Id.

162. Id
} 
the Accused."163 This newly appointed section contained all of the language discussed above from the 1997 Guidance Document, but it also told schools "the Family Rights and Privacy Act (FERPA) does not override federally protected due process rights of Persons accused of sexual harassment." 164 The 2001 Guidance concluded by saying, "[s]chools should be aware of these rights and their legal responsibilities to individuals accused of harassment."165 Thus it was understandable based on both the 1997 and 2001 Guidance Documents that an institution would think it could set a standard of proof at clear and convincing evidence or even beyond a reasonable doubt.

In a significant about-face, the DCL deemphasizes the due process rights of respondents. The section entitled, "Due Process of the Accused" is deleted. Missing is any explicit mention of the Constitution's due process guarantee and that rights under Title IX must be interpreted consistently with any federally guaranteed due process rights. Absent is any acknowledgement of additional rights that might have been granted by a state or the particular institution. Instead, in marked contrast to its prior guidelines, the DCL almost begrudgingly states that schools must provide alleged perpetrators with due process. It devotes just one sentence to the rights of the accused: "Public and state-supported schools must provide due process to the alleged perpetrator."166 Tellingly, it follows that sentence by once again emphasizing the rights of alleged victims: "However, schools should ensure that steps taken to accord due process rights to the alleged perpetrator do not restrict or unnecessarily delay the Title IX protections for the complainant." 167

\section{Summary}

Under the "legal effect" test as articulated by American Mining Congress, a "purported interpretive rule" has legal affect if it effectively amends a legislative rule. Although American Mining Congress concerned Program Policy Letters, courts have used the same test to evaluate purported guidance documents, like the DCL. The 2001 Guidance Document is probably a legislative rule. It meets the procedural requirements of a legislative rule because it went through notice and comment. It also

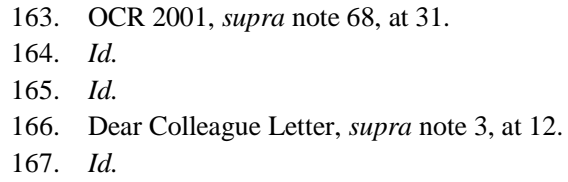


meets two of the substantive parts of a legislative rule in that OCR explicitly invoked its general legislative authority, and on at least one occasion it used mandatory language. Whatever the 2001 Guidance is, there can be little doubt that the DCL effectively amended it. As detailed above, the DCL adds many requirements that are not part of the 2001 Guidance. In addition, the general tone of these changes is to downplay the procedural due process rights of the accused, which is a repudiation of the 2001 Guidance's emphasis on these rights. If a court finds that the DCL effectively amended a legislative rule then it will be deemed procedurally invalid. What is more, even if a court were to find that the 2001 Guidance Document was not a legislative rule, the DCL might still be held invalid if it has the force of law, i.e. impermissibly imposes legal obligations that require legislative rulemaking. ${ }^{168}$

\section{Does the DCL have the Force of Law?}

In General Electric Co. v. Environmental Protection Agency, in an opinion authored by then Chief Judge and now Justice Ruth Bader Ginsburg, the United States Court of Appeals for the District of Columbia was asked to decide whether an Environmental Protection Agency (EPA) Guidance Document was actually a legislative rule. The court wrote that in deciding how to draw the line between legislative rules and statements of policy, "we have considered whether the agency action (1) 'imposes any rights and obligations' or (2) 'genuinely leaves the agency and its decisionmakers free to exercise discretion." "169 It went on further, "if a statement denies the decisionmaker discretion in the area of its coverage, so that [the agency] will automatically decline to entertain challenges to the statement's position then the statement is binding, and creates rights or obligations. ${ }^{170}$

At issue in General Electric was whether the guidelines for how to conduct a risk assessment on sampling, cleaning up or disposing of PCB remediation waste were legislative or merely advisory. General Electric

168. Gen. Elec. Co. v. Envtl. Prot. Agency, 290 F.3d 377, 382 (D.C. Cir. 2002).

169. Id. (quoting Cmty. Nutrition Inst. v. Young, 818 F.2d 943, 946 (D.C. Cir. 1987); Chamber of Commerce v. Dep't of Labor, 174 F.3d 206, 212 (D.C. Cir. 1999)).

170. Id. (quoting McLouth Steel Prod. Corp. v. Thomas, 838 F.2d 1317, 1320 (D.C. Cir. 1988)); see also Miller v. Cal. Speedway Corp., 536 F.3d 1020, 1033 (9th Cir. 2008). In Miller, the Ninth Circuit articulated a similar test: "Interpretive rules merely explain, but do not add to, the substantive law that already exists in the form of a 'statute or legislative rule,' whereas legislative rules 'create rights, impose obligations or affect a change in existing law pursuant to authority delegated by Congress." Id. (quoting Hemp Indus. Ass'n v. DEA, 333 F.3d 1082, 1087 (9th Cir. 2003)). 
had argued that the Guidance document was a legislative rule "because it gives substance to the vague language" of the statute at issue and it "does so in an obligatory fashion." 171 The EPA countered that the Guidance Document did not have the force of law "because it does not purport to be benign and because it has not been applied as though it were binding." ${ }^{172}$ In finding that the Guidelines were legislative, the court emphasized the language of the Guidance Document at issue. It noted that the Document twice used the word "must" and it explained, "To the applicant reading the Guidance Document the message is clear: in reviewing applications the Agency will not be open to considering approaches other than those prescribed in the Document."173

Like the Guidance Document in General Electric, the DCL purports to be a non-binding statement that "does not add requirements to applicable law, but provides information and examples to inform recipients about how OCR evaluates whether covered entities are complying with their legal obligations." 174 As General Electric and other cases show, however, even if an agency purports to be issuing an interpretive rule, courts may still find that it exercises power that can only be invoked in a legislative rule. ${ }^{175}$ "It is well-established that an agency may not escape the notice and comment requirements . . by labeling a major substantive legal addition to a rule a mere interpretation.", "176 A court must "still look to whether the interpretation itself carries the force and effect of law, ... or rather whether it spells out a duty fairly encompassed within the regulation that the interpretation purports to construe." "177

Using the legal effect test as articulated in General Electric, it is clear that the DCL is a legislative rule on its own terms even if the earlier

\footnotetext{
171. Id.

172. Id. at 383 .

173. Id. at 384 .

174. Dear Colleague Letter, supra note 3, at 1 n.1.

175. See Appalachian Power Co. v Envtl. Prot. Agency, 208 F.3d 1015, 1023, 1028 (D.C. Cir. 2000) (holding in a unanimous decision that the guidance document was a legislative rule despite issuing a disclaimer at the beginning of the document saying: "The policies set forth in this paper are intended solely as guidance, do not represent final Agency action, and cannot be relied upon to create any rights enforceable by any party."); see also McLouth Steel Prod. Corp. v. Thomas, 838 F.2d 1317, 1324 (D.C. Cir. 1988) (holding that the EPA's vertical and horizontal spread model is a rule and not a policy).

176. Appalachian Power Co., 208 F.3d at 1024. But see, SBC Inc. v. FCC, 414 F.3d 486, 495 (3d Cir. 2005) (quoting Viacom Int'l, Inc. v. FCC, 672 F.2d 1034, 1042 (2d Cir. 1982)) (“An agency's determination that 'its order is interpretive,' and therefore not subject to notice and comment requirements, 'in itself is entitled to a significant degree of deference."').

177. Appalachian Power Co., 208 F.3d at 1024 (internal citations omitted).
} 
2001 Guidance was not. As explained above, on multiple occasions, OCR tells schools that they must take certain steps in order to be in compliance with Title IX. Specifically, DCL tells schools:

(1) They may only use informal mechanisms to address some forms of sexual harassment. ${ }^{17}$

(2) "Any agreement or Memorandum of Understanding (MOU) with a police department must allow the school to meet its Title IX obligation to resolve complaints promptly and equitably."

(3) "Although a school may need to delay temporarily the fact-finding portion of at Title IX investigation while the police are gathering evidence, once notified that the police department has completed its gathering of evidence (not the ultimate outcome of the investigation or the filing of any charges), the school must promptly resume and complete its fact-finding for the Title XI investigation." 180

(4) “... [I]n order for a school's grievance procedures to be consistent with Title IX standards, the school must use a preponderance of the evidence standard."181

(5) "(T)he parties must have an equal opportunity to present witnesses and other evidence." 182

(6) "The complainant and the alleged perpetrator must be afforded similar and timely access to any information that will be used at the hearing.","183

(7) "If a school chooses to allow the parties to have their lawyers participate in the proceedings, it must do so equally for both sides."

(8) "If a school provides for appeal of the findings or remedy, it must do so for both parties." 185

(9) "Both parties must be notified, in writing, about the outcome of both the complaint and any appeal.",186

\footnotetext{
178. Dear Colleague Letter, supra note 3, at 8 (emphasis added).

179. Id. at 10 (emphasis added).

180. Id. (emphasis added).

181. Id. at 11 (emphasis added).

182. Id. (emphasis added).

183. Id. (emphasis added).

184. Id. at 12 (emphasis added).

185. Id. (emphasis added).

186. Id. at 13 (emphasis added).
} 
(10) Schools must have policies and procedures to protect against retaliatory harassment, ${ }^{187}$ and they must ensure that both complainants and their parents know how to report problems. ${ }^{188}$

(11) "(I)f a school determines that sexual harassment that creates a hostile environment occurred, it must take immediate action to eliminate the hostile environment, prevent its recurrence, and address its effects." 189

"On its face" the DCL "imposes binding obligations" upon schools. ${ }^{190}$ It does not leave "the agency and its decisionmakers free to exercise discretion." "191 Just as in Appalachian Power Co. v. Environmental Protection Agency, "[ $\mathrm{t}]$ he entire Guidance, from beginning to end ... reads like a ukase. It commands, it requires, it orders it dictates." 192 In other words, the DCL has "the force of law."193 Such language also specifically violates OMB's Final Bulletin for Agency Good Guidance Practices, which states:

Each significant guidance document shall ... [n]ot include mandatory language such as "shall," "must," "required"' or "requirement," unless the agency is using these words to describe a statutory or regulatory requirement, or the language is addressed to agency staff and will not foreclose agency consideration of positions advanced by affected private parties.

Since the DCL is a procedural rule and did not go through either formal or informal rulemaking, it is procedurally invalid, and universities have no legal obligation to adhere to it.

\section{Has the DCL Effectively Left Schools No Other Choice?}

Even if the DCL does not have the force and effect of law, the DCL has made the consequences for not abiding by it so significant that it is effectively legally binding. In Chamber of Commerce v. U.S. Department of Labor, ${ }^{195}$ the Occupational Safety and Health Administration (OSHA)

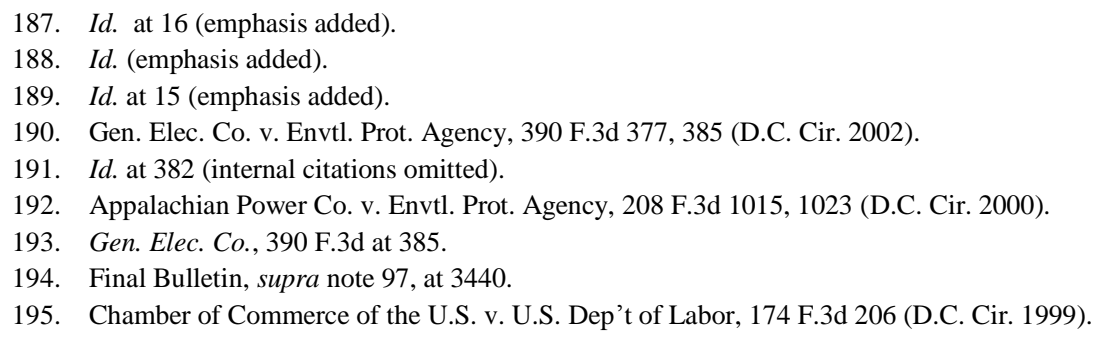


engaged in conduct similar to what DOE has been doing here. At issue was an OSHA directive telling agencies that they would not inspect workplaces as frequently or thoroughly if the employer abided by certain safety standards, which were being set forth for the first time. ${ }^{196}$ The D.C. Circuit struck this directive down as being procedurally invalid on the ground that the burden of inspections was so great that employers had no real choice except to avoid them, which in effect made the directive binding. ${ }^{197}$

Similarly, in the DCL, OCR told academic institutions that if they didn't take certain measures (like lowering the burden of proof) they would be found in violation of Title IX. In an unprecedented move, OCR began publishing a list of universities under investigation for violating Title IX, which put tremendous financial and social pressure on schools to comply with the DCL. Even universities that may believe the DCL is procedurally or substantively invalid are rolling over and complying because the cost of not doing so is simply too high. In essence, OCR's actions have transformed what could have been a legitimate guidance document (if it had not had language that gave it the force of law) into something that is legally binding.

\section{E. Summary}

The DCL effectively amended a legislative rule, which means that it is invalid. Alternately, even if the DCL did not amend a legislative rule it has the force of law, and so could only be promulgated as a legislative rule. In addition, because OCR has made the consequences of not complying with the DCL so deleterious for schools OCR has effectively made the DCL legally binding. The consequence of each and all of these arguments is that the DCL is invalid and that a court should refuse to enforce it.

\section{How SHOULD UNIVERSITIES AdDRESS ALLEGATIONS OF SEXUAL ASSAULT?}

If the DCL is invalid, that leaves the 1997 and 2001 Guidance Documents in place, ${ }^{198}$ which give universities significantly more flexibility

196. Id. at 208 .

197. Id. at 213 .

198. The 2001 Guidance may be procedurally invalid for being a legislative rule. See supra Part II.B.1. The 1997 Guidance, however, does not seem to have this same problem. See supra Part 
in deciding how to address allegations of sexual assault. ${ }^{199}$ Although OCR could try and enforce provisions from the DCL, it would have to do so via individual enforcement actions and without relying on the DCL. Alternatively, OCR could either issue a new guidance document that is procedurally valid, or it could try to promulgate the currently mandatory provisions of the DCL through informal rulemaking, i.e. notice-andcomment rulemaking.

In deciding what processes to put in place, both universities and OCR would be wise to remember Title IX's purpose. Title IX aims to create equality in the classroom, and ending sexual assault and harassment is a necessary means to achieving that end. Thus it is imperative that schools institute processes that give women decision-making power. They must have a say in determining how they want to address what happened to them. Anything short of that undermines Title IX's goal of equality and denies women the respect and dignity they deserve. Granting women a voice in the process is not just important on some metaphysical level; studies show that it is what victims need to recover from trauma. As Mary Koss explains, "[the] consensus of published studies is that sexual assault victims need to ... above all have choice and input into the resolution of their violation." 200

Universities should not rely solely on the threat of external sanctions to protect prospective victims, but also should set up processes that encourage internally driven compliance. ${ }^{201}$ Using the threat of punishment to deter assault (which is what universities are currently doing) is only partially effective. Studies have shown that it is perception of the certainty of punishment (as opposed to the magnitude of the punishment) that drives individuals to change their behavior. ${ }^{202}$ An external punishment model of social control is particularly unsuited for sexual assault,

II.B.1.

199. The DCL explicitly states that it "supplements the 2001 Guidance by providing additional guidance and practical examples regarding the Title IX requirements as they relate to sexual violence." Dear Colleague Letter, supra note 3, at 2. If the DCL were vacated for being procedurally invalid, that would leave the 2001 Guidance Document in place.

200. Mary P. Koss et al., Campus Sexual Misconduct: Restorative Justice Approaches to Enhance Compliance with Title IX Guidance, 15 Trauma, Violence, \& ABuse 242, $246-47$ (2014).

201. See Tom Tyler, Restorative Justice and Procedural Justice: Dealing with Rule Breaking, 62 J. SOC. ISSUES 307, 315 (2006).

202. Daniel S. Nagin, Criminal Deterrence Research at the Outset of the Twenty-First Century, 23 CRIME \& JUST. 1, 7 (1998); see generally Aaron Chalfin \& Justin McCrary, Criminal Deterrence: A Review of the Literature, J. ECON. LITERATURE (forthcoming), http://eml.berkeley.edu/ jmccrary/chalfin_mccrary2015b.pdf (finding that severity of punishment is not the greatest contributor to deterrence). 
an underreported crime that usually happens behind closed doors without witnesses and, consequently, is the type of setting where police are unlikely to be. As will be explained below, universities should offer restorative justice processes and make sure that any adjudicatory processes provide procedural justice.

\section{A. Restorative Justice}

Restorative justice processes (RJ) offer particular promise. As Tom Tyler explains: "Restorative Justice argues that the social goal that should dominate reactions to transgressions is to resolve the dispute via reintegrative shaming [which] ... combines strong disapproval of bad conduct with respect for the person who committed those bad acts. The goal is restoring victims, offenders and the community." 203 Unlike mediation, which treats parties as neutral, the starting point for RJ is that "harm has been done and someone is responsible for repairing it." 204 This distinction is important because the 1997 Guidance Document ${ }^{205}$ and the 2001 Guidance Document ${ }^{206}$ told schools that they could not use mediation in cases of sexual assault, even if voluntary. Importantly, however, both the 1997 Guidance $^{207}$ and the 2001 Guidance $^{208}$ specifically stated that schools could use informal mechanisms in resolving sexual harassment complaints if both parties agreed. Since RJ is fundamentally different than mediation in terms of the way that it situates the parties, it would seem to be permissible under both the 1997 and 2001 Guidance Documents.

RJ provides a marked contrast to the way that OCR has told schools to handle sexual assault. The OCR approach could be characterized as "progressive exclusion" meaning that as the seriousness of the offense increases, the offender is further separated from the institution. ${ }^{209}$ This

203. See Tyler, supra note 201, at 315.

204. See Koss et al., supra note 200, at 246. Koss argues that this distinction is important: Judicial "responses to sexual misconduct must acknowledge and obviate the negative effects of societal and individual norms that operate to silence victims and create opportunities for reabuse. When someone has been harmed by another person, mediation that provides neutrality and treats parties as equal partners in the resolution process is inappropriate." Id. at 245-46. Koss also argues that because of this difference, colleges can adopt RJ and not be in violation of the DCL. Id. at 246.

205. OCR 1997, supra note 54.

206. OCR 2001, supra note 68, at 21.

207. OCR 1997, supra note 54.

208. OCR 2001, supra note 68, at 21.

209. David R. Karp \& Olivia Frank, Restorative Justice \& Student Development in Higher Education: Expanding “Offender” Horizons Beyond Punishment and Rehabilitation to Community En- 
approach may increase community safety and convey community disapprobation, but it "directly conflicts with the aspirations of rehabilitation and reintegration, which aim to restore the student's personal well-being and relationship to their school community." 210 In addition, unlike RJ, traditional disciplinary proceedings are only able to address the assault on a micro level (between the parties involved) instead of looking beyond to the forces that helped to create the situation in the first place.

Although RJ is geared towards reintegrating the transgressing student back into the community, it is also dedicated to helping the victim heal and move forward. "A consensus of published studies is that sexual assault victims need to tell their own stories about their own experiences, obtain answers to questions, experience validation as a legitimate victim, observe offender remorse for harming them, (and) receive support that counteracts isolations and self-blame." 211 RJ responds to these needs. In conferencing (the most widely used model of RJ), the first meeting begins with the responsible person (otherwise known as the respondent or the accused) describing and taking responsibility for what he did and the victim describing the impact of the violation. ${ }^{212}$ Family and friends of both are present for support and are given the opportunity to explain the impact of the harm. ${ }^{213}$ A written redress plan is later formalized that describes "the concrete means through which the responsible person will be held accountable and remedy the impacts on victims and the community." 214 This can include counseling (sex offender treatment, drug and alcohol interventions, and anger management), community service, and victim restitution. ${ }^{215}$ A one-year supervision period is put in place to monitor the responsible person and make sure that he meets his commitments. ${ }^{216}$

$\mathrm{RJ}$ has been shown to be effective at lowering recidivism and empowering victims in both academic and non-academic settings. A 2014 study by David Karp and Casey Sacks compared outcomes across three different college disciplinary processes: model code (a term used for the more traditional hearing conducted by a single hearing officer or pan-

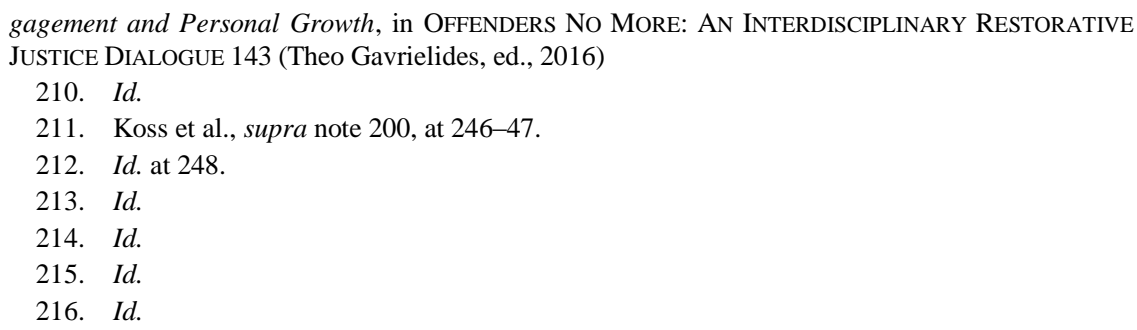


el), ${ }^{217}$ restorative justice, and a combination of the two. ${ }^{218}$ Karp and Casey used data from the STARR project, which has a total of 659 complete cases, ${ }^{219}$ gathered from 18 colleges and universities across the U.S. ${ }^{220}$ Although they cautioned that their results may be limited by the fact that they had few suspension-level cases, their findings showed that RJ provided a positive alternative to more traditional disciplinary proceedings. They "consistently found that restorative justice practices have a greater impact on student learning than model code hearings."221

More significantly, RJ has been successfully adopted for juvenile sex offenses and adult sex crimes. RESTORE is one such program that uses conferencing, a widely used RJ methodology. ${ }^{222}$ Koss evaluated RESTORE using a sample of 66 cases involving sex crimes. Although caution is necessary due to the small sample size, the results are promising. Koss found that $63 \%$ of victims and $90 \%$ of responsible persons chose RJ; $80 \%$ of responsible persons completed all elements of their redress plan within one year (12 months), and post-conference surveys showed that in excess of $90 \%$ of all participants, including the victims, agreed that they felt supported, listened to, treated fairly and with respect, "and believed that the conference was a success."223 Importantly, there were no incidents involving physical threats, and standardized assessments showed decreases in victim posttraumatic stress disorder symptoms from intake to post conference. ${ }^{224}$

But perhaps the most persuasive case for RJ can be made from listening to victims who have participated in the process. In 2014, the dental school at Dalhousie University in Canada was rocked by a scandal in which male students were posting sexist remarks about female students on a private FACEBOOK page. ${ }^{25}$ The female students elected to go

217. David R. Karp \& Casey Sacks, Student Conduct, Restorative Justice, and Student Development: Findings from the STARR Project: A Student Accountability and Restorative Research Project, 17 CONTEMP. JUST. REV. 154, 156 (2014). "The model code calls for a hearing process that is conducted by a single hearing officer or a volunteer board, often composed of students, faculty, and staff. While proponents of the model code highlight that the hearing is not a criminal trial, it has many of the similarities to the courtroom process." Id.

218. See id.

219. Id. at 162 .

220. Id. at 160 .

221. Id. at 169 .

222. See Koss et al., supra note 200, at 248.

223. Id. (internal citation omitted).

224. Id.

225. Jennifer J. Llewellyn et al., RePORT FROM the Restorative Justice Process AT the $\begin{array}{llllll}\text { DALHOUSIE UNIVERSITY FACULTY OF DENTISTRY } & 2 & \text { (2015), }\end{array}$ 
through a restorative justice process despite considerable external pressure to do otherwise. At the end, the women released a written statement in which they explained why it was so important for them to have control over the process and how much they had gained from restorative justice:

\begin{abstract}
We made this choice informed of all of the options available to us and came to our decision independently and without coercion. ... Many people (some with good intentions) have spoken about us and in the process often attempted to speak for us in ways that we have experienced as harmful silencing and retraumatizing. Our perspective and decision to proceed through this process has often not been honoured or trusted but dismissed or criticized based on the decisions or perspectives of others. We are strong, well-educated professional women with words of our own to explain what we are going through and how we want to proceed. ... The restorative process has provided a very important space for us to engage safely and respectfully with our colleagues and others to convey our perspectives and needs. The process allows us to be involved in a manner that both respects and values our unique perspectives and the level of commitment and connection we desire. Additionally, it allows us to address underlying systemic and institutional issues influencing the climate and culture in which we live and learn. We want this process to make a significant contribution to bringing about a change in that culture and hope that we will be given the respect, time and space needed to do this work. ${ }^{226}$
\end{abstract}

Prominent scholars like Mary $\operatorname{Koss}^{227}$ and Donna Coker ${ }^{228}$ have called for universities to include RJ in addressing allegations of sexual assault. Koss has outlined how RJ can be used not solely as an alternative resolution process but also as a complement to a formal adjudicatory hearing. ${ }^{229}$ For instance, it could be used as a sanctioning process (to determine the appropriate sanction after a finding of responsibility has been made) and as a reintegration process once the responsible student has finished his sanction. However RJ is used, Coker emphasizes that the responsible person's statements during RJ proceedings must be protected so that they cannot be used by the state in a future prosecution, otherwise $\mathrm{RJ}$ will just become a discovery gathering opportunity for the state. ${ }^{230}$

\footnotetext{
http://www.dal.ca/content/dam/dalhousie/pdf/cultureofrespect/RJ2015-Report.pdf.

226. Id. at app. A, at 67-68.

227. See Koss et al., supra note 200.

228. See Donna Coker, Restorative Justice Responses to Sexual Assault on Campus (2016) (unpublished manuscript) (on file with author).

229. See Koss et al., supra note 200, at 250, 252-53

230. See Coker, supra note 228, at 25-26.
} 


\section{B. Procedural Justice}

If both parties cannot agree to an alternative process then schools must turn to formal adjudication. Under pressure from the DOE, universities have lowered procedural protections afforded to those students accused of sexual assault. ${ }^{231}$ They have also been encouraged by the White House to move (and many have) to an investigatory process in which there is no formal hearing, and it is often a single individual who investigates and determines whether a violation occurred. ${ }^{232}$ This pivot away from process is a grave mistake and should be corrected immediately.

Because being found responsible for sexual assault can be devastating for the accused student, robust procedural protections are warranted. Although a university cannot sentence a student to custody, it can suspend or expel that student. While some commentators downplay the seriousness of such a punishment, individual stories show otherwise. A young man named Joseph Roberts, for example, has described the impact of an email he received two weeks before his scheduled graduation stating that he was being removed from campus due to a complaint of sexual assault. $^{233}$ The email stated that he would be subject to expulsion and arrest if he returned. ${ }^{234}$ There was never a hearing in the case, and Roberts never received his diploma. ${ }^{235}$ Roberts was so distraught that he attempted suicide. ${ }^{236}$

Apart from reputational stigma that results from being found responsible for a sex offense, ${ }^{237}$ being expelled can seriously diminish a person's future career prospects and overall happiness. Studies have shown that earning a college degree has been positively linked to a multitude of benefits, including better health, longer life, a more fulfilling workplace,

231. See Tamara Rice Lave, Ready, Fire, Aim: How Universities Are Failing the Constitution in Sexual Assault Cases, 48 ARIz. ST. L.J. (forthcoming 2016); Tamara Rice Lave, A Critical Look at how Private Universities Adjudicate Rape, U. MIAMI L. REV. (forthcoming 2016).

232. White House Task Force to Protect Students from Sexual Assault, Not Alone: The First Report of the White House Task Force to Protect Students from Sexual Assault, NotAlone.gov (April 2014), https://www.notalone.gov/assets/report.pdf; see Ready, Fire, Aim, supra note 231.

233. See Cathy Young, A Real Dialogue for a Change, WeEkly StANDARD (Jan. 25, 2016), http://www.weeklystandard.com/a-real-dialogue-for-a-change/article/2000597. This author was the co-organizer of this panel and was present for Joseph Roberts's remarks.

234. Id.

235. Id.

236. Id.

237. Ariel Kaminer, Accusers and the Accused, Crossing Paths at Columbia University, N.Y. TiMES (Dec. 21, 2014), http://www.nytimes.com/2014/12/22/nyregion/accusers-and-the-accusedcrossing-paths-at-columbia.html?_r=0. 
and higher lifetime earnings. ${ }^{238}$ Graduating from college is particularly important for those coming from disadvantaged backgrounds. A 2011 study found that, "the chances of achieving economic success are independent of social background among those who attain a BA."239

It is not just the accused that benefits from a fair adjudicatory process-so does the community as a whole. Although many believe that it is the threat or use of punishment that shapes compliance with the law, ${ }^{240}$ social psychologists like Tom Tyler contend that legitimacy is a more powerful force. "Legitimacy is a feeling of obligation to obey the law and to defer to the decisions made by legal authorities."241 In his 1990 book Why People Obey the Law, Tyler argued that the basis of legitimacy is procedural justice. ${ }^{242}$ Subsequent research laid out the six components of procedural justice: representation (the belief to which parties believe they had the opportunity to take part in the decision-making process); consistency (similarity of treatment over time and as compared with like parties); impartiality (when the legal authority is unbiased); accuracy (ability to make competent, high quality decisions which includes the public airing of the problem); correctability (whether the legal system has a mechanism for correcting mistakes); and ethicality (when the authorities treat parties with dignity and respect. $)^{243}$ Importantly, Tyler found that it was perceived fairness and not case outcome that influenced people's evaluation of their courtroom experience. ${ }^{244}$

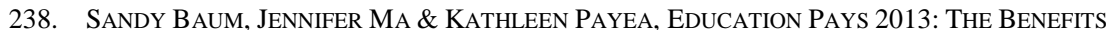
OF Higher EdUCATION FOR INDIVIDUAls AND SOCIETY, COLL. BD. 5-8 (2013), https://trends.collegeboard.org/sites/default/files/education-pays-2013-full-report.pdf; HowARD R. Bowen, InVestment in Learning: The Individual and Social Value of American Higher EDUCATION 219-35 (1977); see generally LARRY L. LESLIE \& PAUL T. BRINKMAN, THE ECONOMIC VALUE OF HIGHER EDUCATION (1988).

239. Florencia Torche, Is a College Degree Still the Great Equalizer? Intergenerational Mobility Across Levels of Schooling in the United States, 117 A. J. OF Soc. 763, 798 (2011) ("The finding is largely consistent across all indicators of socioeconomic standing: social class, occupational status, individual earnings, and total family income.").

240. See Nagin, supra note 202, at 3 (Nagin noted, while reviewing studies on the impact of deterrence: "I now concur with Cook's more emphatic conclusion that the collective actions of the criminal justice system exert a very substantial deterrent effect.").

241. Tom R. Tyler \& Jeffrey Fagan, Legitimacy and Cooperation: Why Do People Help the Police Fight Crime in Their Communities?, 6 OHIO ST. J. CRIM. L. 231, 235 (2008).

242. Tom R. Tyler, Why People Obey the LAW 3-4 (2006); see also TOM R. TYLER \& YueN J. Huo, Trust in the LAw: ENCOURAGing Public COOPERATION With the POLICE AND COURTS 7-18 (2002); Tom R. Tyler, Psychological Perspectives on Legitimacy and Legitimation, 57 ANN. REV. PSYCHOL. 375, 384 (2006).

243. See Raymond Paternoster et al., Do Fair Procedures Matter? The Effect of Procedural Justice on Spouse Assault, 31 LAW \& SoC'Y REV. 163, 167-69 (1997).

244. Tom R. Tyler, The Role of Perceived Injustice on Defendants' Evaluations of Their Court- 
The importance of procedural justice explains why universities must not ignore the outcry among many students and faculty that campus proceedings are unfair. Tyler explains:

\begin{abstract}
Research makes clear that people feel that authorities are entitled to be obeyed when they exercise authority using fair procedures. Further, the use of fair procedures leads people to feel that the authorities share their moral values. In both cases, the key psychological mechanism is the activation of internal social values, which then motivate self-regulatory behavior. $^{245}$
\end{abstract}

In other words, if students believe they are being treated fairly, they will be more likely to follow campus codes of conduct. As noted above, courts are starting to rule that universities have deprived students of basic procedural protections. ${ }^{246}$ Schools would be wise to fix these proceedings on their own rather than waiting for courts to force them to change. Acting on their own demonstrates that schools believe in procedural fairness; being forced to act conveys the opposite.

\title{
1. Recommended Protections
}

The 2001 Guidance Document acknowledged, as it must, that, "[t]he rights established under Title IX must be interpreted consistent with any federally protected due process rights involved in a complaint proceeding." 247 What those protections should look like to satisfy due process has been more fully developed elsewhere, ${ }^{248}$ but a brief summary is in order. To begin with, students facing suspension or expulsion should have the right to a full adjudicatory hearing in which witnesses testify and evidence is presented. The investigatory model that some schools are using is gravely flawed. As the court explained in Doe v. Brandeis

\footnotetext{
room Experience, 18 LAW \& SOC'Y REV. 51, 51 (1984).

245. Tyler, supra note 201, at 315.

246. See infra Part III.B.1.

247. OCR 2001, supra note 68, at 22.

248. See Ready, Fire, Aim, supra note 231 (discussing the procedural protections public universities should afford in order to meet their obligations under the constitution and to promote feelings of legitimacy among their student body); see also A Critical Look, supra note 231 (arguing that by using the threat of removing federal funding to force universities to lower their procedural protections, OCR has essentially turned private action into state action, and private universities, therefore, must also comply with procedural due process).
} 
University: "The dangers of combining in a single individual the power to investigate, prosecute, and convict, with little effective power of review, are obvious. No matter how well-intentioned, such a person may have preconceptions and biases, may make mistakes, and may reach premature conclusions." 249

At that hearing, the accused student should have the right to a trained advocate provided by the school (not necessarily a lawyer). Although such an advocate is unlikely to be constitutionally required, it makes sense from a procedural justice standpoint since an advocate will provide important assistance during a high-stakes proceeding and enhance the hearing's accuracy. Students also should have the right to directly question their accuser, which as the court in Doe v. Brandeis University explained, is particularly important in credibility contests where there are no witnesses or other extrinsic evidence. ${ }^{250}$ To allow the pursuit of truth while avoiding unnecessary trauma to the complainant, schools should have the advocate undertake the direct questioning rather than the respondent himself.

Students must also have sufficient advance notice of what they are alleged to have done so that they can prepare their defense. In Goss $v$. Lopez, the U.S. Supreme Court held that public high school students facing suspension had a property interest in their education and a liberty interest in their good name. ${ }^{251}$ At a minimum, the Court held that "the student [must] be given oral or written notice of the charges against him and, if he denies them, an explanation of the evidence the authorities have and an opportunity to present his side of the story." 252 Lopez carefully distinguished between the initial notice requirement and what a school has to provide once a student has denied the charges. The initial notice requirement is not that rigorous and requires only that a student "first be told what he is accused of doing and what the basis of the accusation is." 253 If the student denies the charges, however, the university has a higher burden and must provide "an explanation of the evidence the

\footnotetext{
249. Doe v. Brandeis Univ., No. 15-11557-FDS, 2016 WL 1274533, at *36 (D. Mass. Mar. 31, 2016).

250. Id. at *12.

251. Goss v. Lopez, 419 U.S. 565, 584 (1975).

252. Id. at 581 .

253. Id. at 581-82. The Second Circuit has explained that "[n]otice must be 'reasonably calculated, under all the circumstances, to apprise interested parties of the pendency of the action and afford them an opportunity to present their objections." Rosa R. v. Connelly, 889 F.2d 435, 439 (2d Cir. 1989) (quoting Mullane v. Cent. Hanover Bank \& Trust Co., 339 U.S. 306, 313 (1950)).
} 
authorities have against him."254

This distinction is important because a university might argue that it is complying with its due process obligations by providing the accused with a synopsis of the accusations through its Title IX coordinator. This notice, however, only meets its notice obligation, not its more weighty obligations under the "explanation of evidence" portion of Lopez. Indeed, part of the reason that the Massachusetts District Court held that John Doe's procedural rights were violated was that, "[h]e was required to defend himself in what was essentially an inquisitorial proceeding that plausibly failed to provide him with a fair and reasonable opportunity to be informed of the charges and to present an adequate defense."255

\section{Raising the Burden of Proof}

Whether or not constitutionally required, schools should consider setting the standard of proof at clear and convincing evidence. ${ }^{256}$ OCR tried to mandate a preponderance of the evidence standard through the DCL, but preponderance is simply too low for what is at stake for the accused student. In Addington v. Texas, the Court said that the function of the standard of proof is to "instruct the factfinder concerning the degree of confidence our society thinks he should have in the correctness of factual conclusions for a particular adjudication." 257 Setting a high or low standard is a way of "allocate[ing] the risk of error between the litigants and indicat[ing] the relative importance attached to the ultimate decision., 258

Although a student will not go to jail if the student is found to have violated the school of conduct, the student's life will almost certainly still be gravely affected. The Family Educational Rights and Privacy Act (FERPA) generally prohibits the improper disclosure of personally identifiable information obtained from education records, but there are exceptions for crimes of violence. ${ }^{259}$ Universities are required to notify the victim of the outcome of the proceedings, ${ }^{260}$ and they are allowed to dis-

254. Goss, 419 U.S. at 581

255. Brandeis Univ., $2016 \mathrm{WL} 1274533$, at $* 37$.

256. See Ready, Fire, Aim, supra note 231; see also A Critical Look, supra note 231.

257. Addington v. Texas, 441 U.S. 418, 423 (1979) (citing In re Winship, 397 U.S. 358, 370 (1970)).

258. Id. at 423 .

259. 34 C.F.R. $\$ 99.31$, App. A (2012).

260. 34 C.F.R. $\$ 99.31(a)(13)$ (2012). 
close to third parties when they find that a student has committed rape or sexual assault. ${ }^{261}$ A number of universities mark official transcripts to indicate that the person committed non-academic misconduct. ${ }^{262}$ Although some students have the savvy and resources to transfer to another school after being expelled, many do not. Without an undergraduate degree, a person's earning potential and career opportunities are significantly curtailed.

The DCL states that the preponderance of the evidence standard is justified on the ground that the Supreme Court uses a preponderance standard in civil litigation under Title VII, and that the OCR uses the preponderance standard when it resolves complaints against recipients of federal funds. ${ }^{263}$ This may be true, but it does not explain why the standard should be preponderance in campus disciplinary hearings. After all, only an institution or an institutional actor can violate Title IX, as is obvious from the language of the statute: "No person in the United States shall, on the basis of sex, be excluded from participation in, be denied the benefits of, or be subjected to discrimination under any education program or activity receiving Federal financial assistance."264 As the Court explained in Gebser: "Title IX focuses more on 'protecting' individuals from discriminatory practices carried out by recipients of federal funds." 265

The question then is whether allowing universities to set the standard of proof at a standard higher than preponderance either (1) supports discriminatory practices or (2) denies individuals effective protection against such practices. Setting the burden of proof so high that a finding of culpability is almost impossible would certainly constitute a discriminatory practice, but it seems unlikely that clear and convincing evidence would have that effect. Indeed, the standard of proof at a criminal trial is beyond a reasonable doubt, and defendants are still convicted of rape, even in cases where the only evidence that the sex was non-consensual is the victim's testimony. ${ }^{266}$

\footnotetext{
261. 34 C.F.R. $\S 99.31(a)(14)$ (2012).

262. Collin Binkley et al., Students Transfer Easily after Violent Offenses, THE ColumBus Dis-

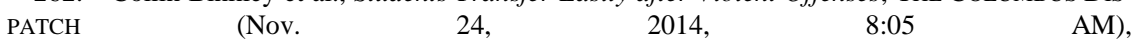
http://www.dispatch.com/content/stories/local/2014/11/24/hidden-on-campus.html.

263. Dear Colleague Letter, supra note 3, at 11-12.

264. 20 U.S.C. $\$ 1681$ (a) (2012).

265. Gebser v. Lago Vista Indep. Sch. Dist., 524 U.S. 274, 287 (1998) (citing Cannon v. Univ. of Chi., 441 U.S. 677, 702 (1979))

266. See Bill Redeker, Rapist Convicted on Victim's Testimony, ABC NEws (Aug. 28, 2004), http://abcnews.go.com/WNT/story?id=129479; Vanessa Junkin, Teen Convicted of Rape in High
} 
Furthermore, requiring that the standard of proof be set at preponderance means that some schools have a lower standard of proof for allegations of sexual harassment or assault than for other offenses. ${ }^{267}$ As the Massachusetts District Court observed in Doe v. Brandeis University, intentionally making it easier to find men responsible for sexual assault compared to other misconduct is particularly problematic in light of the elimination of other basic procedural rights of the accused:

The standard of proof in sexual misconduct cases at Brandeis is proof by a "preponderance of the evidence." For virtually all other forms of alleged misconduct at Brandeis, the more demanding standard of proof by "clear and convincing evidence" is employed. The selection of a lower standard (presumably, at the insistence of the United States Department of Education) is not problematic, standing alone; that standard is commonly used in civil proceedings, even to decide matters of great importance. Here, however, the lowering of the standard appears to have been a deliberate choice by the university to make cases of sexual misconduct easier to prove-and thus more difficult to defend, both for guilty and innocent students alike. It retained the higher standard for virtually all other forms of student misconduct. The lower standard may thus be seen, in context, as part of an effort to tilt the playing field against accused students, which is particularly troublesome in light of the elimination of other basic rights of the accused. $^{268}$

3. Mandating Preponderance of the Evidence while Ignoring other Title VII Protections

From a procedural justice standpoint, OCR's justification for setting the standard of proof at preponderance of the evidence is particularly problematic. OCR argues that the standard of proof should be preponderance because that is what the government uses in Title VII hearings. If OCR wants to base its procedural protections on Title VII, however, then it should require all of the same rights afforded at Title VII hearings. Under Title VII, the EEOC is barred from releasing the names of those under investigation, ${ }^{269}$ and if someone does release a name, they will be fined, jailed, or both. ${ }^{270}$ If the DCL wants to pattern its proceed-

\footnotetext{
School Hallway, USA TODAY (Oct. 22, 2014, $7: 49 \quad$ AM), http://www.usatoday.com/story/news/nation/2014/10/21/teen-convicted-of-rape-in-high-schoolhallway/17699211/.

267. See Ready, Fire, Aim, supra note 231; see also A Critical Look, supra note 231.

268. Doe v. Brandeis Univ., No. 15-11557-FDS, 2016 WL 1274533, at*37 (D. Mass. Mar. 31, 2016).

269. 42 U.S.C. $§ 2000$-5(b) (2012) (“Charges shall not be made public by the Commission.”).

270. Id.
} 
ings on those under Title VII, then it should also penalize releasing the names of schools under investigation.

In addition, the Civil Rights Act of 1991 gives both parties in a Title VII case the right to a jury trial if one party requests compensatory or punitive damages. ${ }^{271}$ Having the right to trial under Title VII means that employers enjoy a panoply of other protections including: the right to counsel; the right to a jury ${ }^{272}$ comprised of jurors who have not been excluded on account of race or gender, ${ }^{273}$ the right to strike jurors for cause, ${ }^{274}$ the right to three peremptory challenges; ${ }^{275}$ the right to confront and cross-examine witnesses (including the complainant); the right to depose witnesses; and the right to the rules of evidence (thus barring hearsay evidence unless it is subject to a recognized exception). Finally, an employer cannot be found responsible for violating Title VII unless the jurors are unanimous. ${ }^{276}$

Not only does the DOE not mandate or even recommend that these rights provided by Title VII be provided, the DCL affirmatively recommends against some of them. For instance, OCR strongly discourages schools from allowing the parties to directly question one another, ${ }^{277}$ and it tells schools that they "should not allow the alleged perpetrator to review the complainant's statement without also allowing the complainant to review the alleged perpetrator's statement." 278 Cherry picking the provisions of Title VII that lower a student's procedural rights while ignoring the provisions that strengthen them undermines the legitimacy of a school's disciplinary proceedings because accused students will understandably feel like they are not being treated fairly.

\section{CONCLUSION}

The DCL is a legislative rule, and because it did not go through no-

\footnotetext{
271. Civil Rights Act of 1991, Pub. L. No. 102-166, 105 Stat. 1071-1100 (codified as amended in scattered sections of 42 U.S.C.).

272. FED. R. CIV. P. 48.

273. In Edmonson v. Leesville Concrete Co., 500 U.S. 614 (1991), the Court held that the prohibition against discriminatory peremptory challenges applies in civil cases. This includes race (Batson v. Kentucky, 476 U.S. 79, 87-98 (1986)), ethnicity (Hernandez v. New York, 400 U.S. 352 (1991)), and gender (J.E.B. v. Alabama, 511 U.S. 127 (1994)).

274. 28 U.S.C. $\$ 1870(2012)$.

275. Id.

276. FED. R. CIV. P. 48.

277. Dear Colleague Letter, supra note 3, at 11-12.

278. Id
} 
tice-and-comment, it is procedurally invalid. Courts should vacate it, which would leave the 2001 or 1997 Guidance Documents in effect. Both of these Guidance Documents give schools considerable flexibility in determining how they want to adjudicate campus rape. In deciding how to proceed, universities should provide various levels of formality in their proceedings and focus on giving complainants a say in the process that will be pursued. They also should institute processes that encourage internal law abidingness. Universities can achieve this and be in compliance with Title IX if they provide restorative justice processes. They should also increase the procedural protections afforded in disciplinary hearings so that students are more likely to believe that they are being treated fairly. The effect will be greater law abidingness, which translates into fewer victims.

Unfortunately, such a change is unlikely to happen any time soon. Even if a judge would strike down the DCL, she will not have the chance to do so unless it is actually challenged in court. Colleges and universities are unlikely to do this because of the considerable pressure they face. Supporters of the DCL approach have organized into a public and potent force against universities, ${ }^{279}$ as exemplified by the backlash against the Harvard Law professors who wrote a 2014 op-ed in the Boston Globe criticizing Harvard's post DCL sexual harassment policy as "overwhelmingly stacked against the accused." ${ }^{280}$ Harvard students responded quickly, saying " $[\mathrm{b}] \mathrm{y}$ implying Harvard should disregard its legal obligation to protect all of its students and ensure a safe and anti-discriminatory environment, this piece displays a callous lack of understanding of sexual violence and its effect on survivors in educational institutions." tion, two recent articles have discussed how universities under suspicion for violating Title IX are receiving fewer applications from prospective students and fewer donations from alumni, ${ }^{282}$ which means that schools

279. Emanuella Grinberg, Ending Rape on Campus: Activism Takes Several Forms, CNN (Feb. 12, 2014, 11:35 AM), http://www.cnn.com/2014/02/09/living/campus-sexual-violence-studentsschools/.

280. Opinion: Rethink Harvard's Sexual Harassment Policy, Boston Globe (Oct. 15, 2014), http://www.bostonglobe.com/opinion/2014/10/14/rethink-harvard-sexual-harassmentpolicy/HFDDiZN7nU2UwuUuWMnqbM/story.html.

281. Tyler Kingkade, Harvard Students Slam Law Professors' Claim of Policy Bias Against Accused Rapists, Huffington POST (Oct. 15, 2014, 9:00 PM), http://www.huffingtonpost.com/2014/10/15/harvard-law-professors-sexual-assaultpolicy_n_5993510.html.

282. See Gayle Nelson, The High Cost of Sexual Assaults on College Campuses, NON ProfiT QUARTERLY (June 23, 2015), https://nonprofitquarterly.org/2015/06/23/the-high-cost-of-sexualassaults-on-college-campuses/; see also Tyler Kingkade, Alumni Are Creating a Network to Put 
are likely to simply do what OCR demands instead of waging a reputation damaging court battle.

In the meantime, the Department of Education can continue to pretend that the DCL is just a guidance document while using public shaming to enforce it. As long as OCR continues to publish the names of schools under investigation, they will be under enormous pressure to do what OCR demands, even though it only takes one complaint and no factual finding to make the list. ${ }^{283}$ Thus a school that may want to provide additional procedural protections and institute restorative justice processes - measures that would be fully compliant with Title IX - are unwilling to do so because they deem the cost as simply too high.

Instead, change will have to be achieved piecemeal by individual students fighting their cases in court as has happened in Boston and San Diego. Although a risk-averse school may think it is better to have a judge force them to change their policy, such an approach will only undermine students' faith in the fairness of the school's disciplinary system. Schools would be better served to demonstrate their respect for victim decision-making power by instituting restorative justice processes and to encourage and increase general law abidingness by fostering procedural justice.

Pressure on Universities over Sexual Assault, HuFFington Post (updated May 29, 2014 4:37 PM), http://www.huffingtonpost.com/2014/05/28/alumni-network-sexual-assaultcollege_n_5401194.html.

283. Press Office, U.S. Department of Education Releases List of Higher Education Institutions with Open Title IX Sexual Violence Investigations, DEP'T OF EDUC. (May 1, 2014), http://www.ed.gov/news/press-releases/us-department-education-releases-list-higher-educationinstitutions-open-title-i. 